\title{
Regulation of adaptive immunity; the role of interleukin-10
}

\section{T. H. Sky Ng, Graham J. Britton, Elaine V. Hill, Johan Verhagen, Bronwen R. Burton and David C. Wraith*}

School of Cellular and Molecular Medicine, University of Bristol, Bristol, UK

\section{Edited by:}

Eyad Elkord, United Arab Emirates University, UAE; University of Salford and University of Manchester, UK

\section{Reviewed by:}

Giovanna Lombardi, Kings College London, UK

Bin Li, Chinese Academy of Sciences, China

\section{${ }^{*}$ Correspondence:}

David C. Wraith, School of Cellular and Molecular Medicine, Medical

Sciences Building, University Walk, Bristol BS8 1TD, UK

e-mail:d.c.wraith@bristol.ac.uk
Since the discovery of interleukin-10 (IL-10) in the 1980s, a large body of work has led to its recognition as a pleiotropic immunomodulatory cytokine that affects both the innate and adaptive immune systems. IL-10 is produced by a wide range of cell types, but for the purposes of this review we shall focus on IL-10 secreted by $\mathrm{CD} 4^{+} \mathrm{T}$ cells. Here we describe the importance of IL-10 as a mediator of suppression used by both FoxP3 ${ }^{+}$and $\mathrm{FoxP}^{-}$ $T$ regulatory cells. Moreover, we discuss the molecular events leading to the induction of IL-10 secretion in T helper cell subsets, where it acts as a pivotal negative feedback mechanism. Finally we discuss how a greater understanding of this principle has allowed for the design of more efficient, antigen-specific immunotherapy strategies to exploit this natural phenomenon clinically.

Keywords: allergy, autoimmunity, cytokines, immune regulation, immunotherapy, interleukin-10, regulatoryT cells, T helper cells

\section{THE IMPORTANCE OF IL-10}

Interleukin (IL)-10 is a pleiotropic, immunoregulatory cytokine that is important in protecting the host from infection-associated immunopathology, autoimmunity, and allergy. IL-10 was initially characterized as a $\mathrm{T}$ helper $\left(\mathrm{T}_{\mathrm{H}}\right) 2$ specific cytokine (Fiorentino et al., 1989); however, further investigations revealed that IL10 production was also associated with $\mathrm{T}$ regulatory (Treg) cell responses (Moore et al., 2001; O'Garra and Vieira, 2004; Roncarolo et al., 2006; Sabatos-Peyton et al., 2010). It is now known that almost all cells of both the innate and adaptive arms of the immune system can express IL-10, including dendritic cells (DC), macrophages, mast cells, natural killer cells (NK), eosinophils, neutrophils, $\mathrm{B}$ cells, $\mathrm{CD} 8^{+} \mathrm{T}$ cells, and $\mathrm{T}_{\mathrm{H}} 1, \mathrm{~T}_{\mathrm{H}} 2$, and $\mathrm{T}_{\mathrm{H}} 17 \mathrm{CD} 4^{+} \mathrm{T}$ cells (Maloy and Powrie, 2001; Moore et al., 2001; Fillatreau et al., 2002; Roncarolo et al., 2006; O'Garra and Vieira, 2007; Trinchieri, 2007; Maynard and Weaver, 2008; Sabatos-Peyton et al., 2010; Mauri and Bosma, 2012). For the purposes of this review, we will focus on the expression of IL-10 by CD4 ${ }^{+} \mathrm{T}$ cells and how it acts upon $\mathrm{T}_{\mathrm{H}}$ cells to promote immune homeostasis.

The first IL-10-deficient mouse model was reported 20 years ago and in the past two decades a great deal has been learned about the complex biology of IL-10 by studying this model (Kühn et al., 1993). IL-10-deficient mice exhibit prolonged and exaggerated immune responses toward antigen, in many cases accompanied by excessive inflammation and tissue damage, and they often develop chronic enterocolitis (Kühn et al., 1993; Leon et al., 1998). This pathology is ameliorated under germ-free conditions, suggesting a role for the gut flora in triggering disease and, therefore, a role for IL-10 in regulating homeostatic interactions with commensal microorganisms (Sellon et al., 1998). Similarly, IL10-deficient mice develop prolonged and exacerbated fever in response to lipopolysaccharide (LPS) (Leon et al., 1998) and suffer a lethal immune response to acute infection with Toxoplasma gondii, which is not seen in wildtype animals (Gazzinelli et al., 1996). IL-10-deficiency also aggravates autoimmune pathology in a range of experimental models including rheumatoid arthritis
(RA) (Hata et al., 2004), experimental autoimmune neuritis (Bai et al., 1997), systemic lupus erythematosus (SLE) (Beebe et al., 2002), and experimental autoimmune encephalomyelitis (EAE) (Bettelli et al., 1998).

Several studies of human autoimmune disease have revealed that the level of IL-10 detected in patient samples correlates inversely with disease severity (Hajeer et al., 1998; Lim et al., 1998; Crawley et al., 1999; Van Boxel-Dezaire et al., 1999; Gibson et al., 2001). In multiple sclerosis (MS) patients, low levels of IL-10 mRNA in peripheral blood monocytes (PBMC) are associated with relapse and with secondary progressive disease (Van Boxel-Dezaire et al., 1999). In juvenile onset arthritis, a singlenucleotide polymorphism (SNP) associated with reduced IL-10 mRNA expression correlates with arthritis occurring in a higher number of joints (Crawley et al., 1999). SNPs associated with lower IL-10 mRNA expression are also overrepresented in patients with RA (Hajeer et al., 1998), severe asthma (Lim et al., 1998), and SLE (Gibson et al., 2001).

Together, these studies in mouse and man demonstrate the importance of IL-10 in immune regulation and the impact of IL-10 dysregulation on a wide range of disease states.

\section{THYMICALLY AND PERIPHERALLY GENERATED FoxP3+ REGULATORY T CELLS SECRETE IL-10}

Regulatory $\mathrm{T}$ cells expressing the master transcription factor forkhead box P3 (FoxP3) are essential for immune homeostasis (Chaudhry and Rudensky, 2013). Loss of function mutations within the Foxp3 locus result in congenital Treg deficiency and severe systemic immunopathology in both man (Gambineri et al., 2003) and mouse (Brunkow et al., 2001). Natural, or thymic, Foxp $3^{+}$Tregs (tTreg) develop during selection against self-antigen in the thymus (Fontenot et al., 2003), whereas peripherally induced Foxp $3^{+}$Tregs (pTreg) develop extrathymically in response to antigen-specific stimulation in the presence of transforming growth factor beta (TGF- $\beta$ ) (Curotto de Lafaille et al., 2004). tTregs are implicated in tolerance to self-antigens (Hori 
et al., 2003), whilst pTregs appear to modulate immune responses against both self-antigens not expressed in the thymus and foreign antigens (Pacholczyk et al., 2006; Josefowicz et al., 2012; Samstein et al., 2012). Although several groups have attempted to define a phenotype which distinguishes tTreg and pTreg (Thornton et al., 2010; Weiss et al., 2012; Yadav et al., 2012), at the time of writing, no molecular markers have been identified that can adequately discriminate these two types of Foxp $3^{+}$Treg cells, especially under inflammatory conditions (Verhagen and Wraith, 2010; Gottschalk et al., 2012; Weiss et al., 2012; Himmel et al., 2013).

FoxP3 ${ }^{+}$Tregs are able to secrete IL-10 and this appears to be particularly important in regulating immune responses at the body's environmental interfaces (Uhlig et al., 2006; Maynard et al., 2007; Rubtsov et al., 2008). Mice with selective knockout of IL-10 in Foxp3-expressing cells (IL-10 $0^{\mathrm{f} / \mathrm{fl}} \times$ FoxP3-cre) do not develop spontaneous systemic autoimmunity but do develop spontaneous colitis in a similar manner to germline IL-10-knockout animals (Rubtsov et al., 2008). These mice also develop heightened lung inflammation following intranasal challenge with ovalbumin (OVA), characterized by increased IL-5, IL-13, and interferongamma (IFN- $\gamma$ ) mRNA in lung tissue (Rubtsov et al., 2008). IL- $10^{\mathrm{fl} / \mathrm{fl}} \times$ FoxP3-cre mice exhibit exacerbated skin hypersensitivity when challenged with dinitrofluorobenzene (Chang et al., 2002). The secretion of IL-10 by FoxP3 ${ }^{+}$Treg cells is also important in regulating immune responses against self-antigens in some animal models. In the non-obese diabetic (NOD) mouse model of Type 1 diabetes, disease progression is associated with gradual loss of pancreatic IL-10-secreting FoxP3 ${ }^{+}$Tregs (Kornete et al., 2012). In this model, inducible T cell costimulator (ICOS) blockade results in reduced IL-10 secretion by $\mathrm{ICOS}^{+}$FoxP3 $^{+}$Tregs and this is associated with exacerbated diabetes (Kornete et al., 2012). Regulation of murine $\mathrm{T}_{\mathrm{H}} 17$ responses by FoxP3 ${ }^{+}$Tregs is dependent upon a Treg-specific IL-10-induced transcriptional program, which includes signal transducers and activators of transcription (STAT)3 dependent induction of Treg-derived IL-10 (Chaudhry et al., 2011). Selective deletion of IL-10RA on FoxP3 ${ }^{+}$ Tregs reduces their expression of IL-10 and renders them unable to prevent IL-17-mediated pathology (Chaudhry et al., 2011).

\section{FoxP3- REGULATORY T CELLS SECRETE IL-10}

Following stimulation under specific conditions, naïve $\mathrm{CD}^{+} \mathrm{T}$ cells can differentiate into a population of FoxP3 ${ }^{-}$, IL-10-secreting T cells with potent regulatory capacity (Groux et al., 1997). Often termed type 1 regulatory $\mathrm{T}$ cells $(\operatorname{Tr} 1)$, they are characterized by the expression of high levels of IL-10, sometimes concomitant with IL-5 or IFN- $\gamma$, and low expression of IL-2 and IL-4 (Groux et al., 1997). A recent study found that $\operatorname{Tr} 1$ cells can be identified by CD49b and LAG-3 expression in both human and mice (Gagliani et al., 2013). Tr 1 cells can be generated in vitro from naïve human and murine $\mathrm{CD} 4^{+} \mathrm{T}$ cells by various methods, including repeated $\mathrm{T}$ cell receptor (TCR) stimulation in the presence of high concentrations of exogenous IL-10 (Groux et al., 1997). In in vitro cultures, antigen-presenting cells (APC) are required to generate Tr1 cells from IL-10 treated naïve $\mathrm{CD}^{+} \mathrm{T}$ cells (Gregori et al., 2010). This suggests that IL-10 does not act directly upon naïve $\mathrm{CD} 4{ }^{+} \mathrm{T}$ cells but rather upon APC to render them able to promote Tr1 induction.
In man, a subset of peripheral blood DC, termed DC-10, and characterized by secretion of relatively high amounts of IL-10 and low amounts of IL-12, are particularly able to induce the development of Tr1-like cells in vitro (Gregori et al., 2010). DCs with a similar phenotype to DC-10 cells can also be generated in vitro by culturing human monocytes with IL-4, granulocyte macrophage colony-stimulating factor (GM-CSF) and IL-10 (Gregori et al., 2010). These in vitro-generated DC-10-like cells have comparable function and phenotype to those isolated from peripheral blood and may provide a method for the induction of IL-10secreting T cells for use therapeutically (Gregori et al., 2010). Expression of human leukocyte antigen (HLA)-G and a ligand for the shed extracellular portion of HLA-G, immunoglobulinlike transcript 4 (ILT-4 or LILRB2), are upregulated by IL-10 and have been used to identify a subset of tolerogenic DC in man (Allan et al., 1999; Manavalan et al., 2003; LeMaoult et al., 2004; Gregori et al., 2010). This suggests that IL-10-induced interactions between soluble HLA-G and DC-localized ILT-4, in subsets of DCs including DC-10 cells, is required to induce IL-10secreting $\mathrm{CD}^{+}{ }^{+} \mathrm{T}$ cells from naïve $\mathrm{CD} 4^{+} \mathrm{T}$ cells (Gregori et al., 2010).

In the mouse, IL-27 has been shown to induce Tr1-like cells from naïve $\mathrm{CD}^{+} \mathrm{T}$ cells in vitro (Awasthi et al., 2007). IL-27 induces expression of c-Maf and IL-21 which, in combination with ICOS receptor ligation, act to promote $\operatorname{Tr} 1$ differentiation (Awasthi et al., 2007; Pot et al., 2009). In addition, IL-27 also upregulates the aryl hydrocarbon receptor (AhR) which, when ligated, synergizes with c-Maf to drive IL-10 expression (Apetoh et al., 2010). The secretion of IL-21 by Tr1-like cells can further induce c-Maf expression and, thus, may form an autocrine positive feedback loop promoting IL-10 induction (Pot et al., 2009). Murine DCs can be induced to secrete IL-27 by treatment with recombinant galectin-1. Galectin-1-treated DCs can induce Tr1like cells in vitro, dampen myelin oligodendrocyte glycoprotein (MOG ${ }_{35-55}$ )-induced EAE and antigen-specific proliferation of splenocytes (Ilarregui et al., 2009). Endogenous expression of galectin-1 in DCs is upregulated by IL-10, $1,25(\mathrm{OH})_{2}$-vitamin D3 (VitD3), and galectin-1 itself (Ilarregui et al., 2009; CedenoLaurent et al., 2012). Together these data highlight the importance of the APC in IL-10 induction in naïve CD4 ${ }^{+} \mathrm{T}$ cells in many experimental models.

In man, naïve $\mathrm{CD} 4^{+} \mathrm{T}$ cells can be directed to secrete IL-10, independent of APC, by co-ligation of the TCR and the complement receptor CD46 with either the native ligand, $\mathrm{C} 3 \mathrm{~b}$, or with anti-CD46 antibodies (Kemper et al., 2003; Cardone et al., 2010). The importance of this pathway is reinforced by the observation that $\mathrm{CD} 4{ }^{+} \mathrm{T}$ cells isolated from MS and RA patients demonstrate defective IL-10 secretion in response to stimulation with anti-CD3 and -CD46 antibodies (Astier et al., 2006; Cardone et al., 2010). Ligation of CD46 leads to robust phosphorylation of extracellular signal related kinase 1 and 2 (ERK1/2) which, as will be discussed in more detail below, is a prerequisite for IL-10 expression in $\mathrm{CD} 4^{+} \mathrm{T}$ cells (Zaffran et al., 2001). CD46 is not expressed by murine T cells, limiting the potential to study the role of CD46 in vivo, but transgenic expression of human CD46 in mice leads to elevated serum IL-10 levels following Neisseria meningitides infection (Johansson et al., 2005). 
Tr1-like cells can also be induced in the absence of APC by stimulating naïve murine $\mathrm{CD} 4{ }^{+} \mathrm{T}$ cells with anti-CD3 and -CD28 antibodies in the presence of VitD3, dexamethasone (Dex), and anti-IFN- $\gamma$, -IL-4 and -IL-12 antibodies (Barrat et al., 2002). Neutralization of IL-10 in the culture medium inhibits development of Tr 1 cells (Barrat et al., 2002). In vivo, Tr1 cells can be generated by immunizing mice with cholera toxin (Lavelle et al., 2003, 2004) or treatment with rapamycin and IL-10 (Battaglia et al., 2006).

\section{SELF-LIMITATION OF T HELPER CELLS BY IL-10 SECRETION}

Deviation from normal immune homeostasis, during infection or other insult, will result in tissue damage if allowed to persist following elimination of the target antigen. Similarly, in situations of chronic antigen exposure, such as at mucosal surfaces and in relation to self-antigen, it is essential that regulatory mechanisms exist to restore effector $\mathrm{CD}^{+}{ }^{+} \mathrm{T}$ cell homeostasis. In addition to the regulatory effects of FoxP3 ${ }^{+}$and FoxP3 ${ }^{-}$Tregs, an IL10-dependent negative feedback loop is important in protecting tissues from $\mathrm{T}$ cell-mediated autoimmune disease and infectiondriven immunopathology. For example, wildtype C57BL/6 mice, when primed with MOG in complete Freund's adjuvant (CFA), develop EAE associated with $\mathrm{T}_{\mathrm{H}} 1$ and $\mathrm{T}_{\mathrm{H}} 17$ cytokines, but recover rapidly (Bettelli et al., 1998). In contrast, IL-10-deficient mice do not recover and develop a progressive form of EAE (Bettelli et al., 1998).

\section{$T_{H}$ 17-DERIVED IL-10 IN THE REGULATION OF $T_{H} 17$ RESPONSES}

$\mathrm{T}_{\mathrm{H}} 17$ cells are strongly implicated in many autoimmune conditions traditionally thought to be solely $\mathrm{T}_{\mathrm{H}} 1$-mediated (Steinman, 2007). $\mathrm{T}_{\mathrm{H}} 17$ cells produce IL-17A and IL-17F, which can be detected in target tissues of patients with RA, MS, and SLE (Matusevicius et al., 1999; Linden et al., 2000; Wong et al., 2000; Hashimoto et al., 2005). Experimental colitis, induced by adoptive transfer of IL-17-secreting CD4 ${ }^{+} \mathrm{T}$ cells to Rag-deficient mice, can be suppressed by the co-transfer of IL-10-secreting CD4 ${ }^{+}$ $\mathrm{T}$ cells (Huber et al., 2011). This suppressive effect is dependent on expression of the IL-10 receptor (IL-10R) by the IL-17secreting CD4 ${ }^{+} \mathrm{T}$ cells (Huber et al., 2011). This implies that IL-10 can directly attenuate the pathogenicity of IL-17-secreting CD4 ${ }^{+}$ T cells.

$\mathrm{T}_{\mathrm{H}} 17$ cells have a developmental pathway that overlaps with FoxP3 $^{+}$iTregs (Bettelli et al., 2006). Culturing naïve $\mathrm{CD}^{+}{ }^{+} \mathrm{T}$ cells with TGF- $\beta$ alone drives the generation of FoxP3 ${ }^{+}$iTregs but in combination with the inflammatory cytokine IL- 6 generates $\mathrm{T}_{\mathrm{H}} 17$ cells which express RoR $\gamma \mathrm{t}$ and secrete IL-17 (Figure 1) (Ivanov et al., 2006; McGeachy et al., 2007, 2009). In murine transfer experiments, IL-6- and TGF- $\beta$-generated $\mathrm{T}_{\mathrm{H}} 17$ cells failed to induce EAE; in contrast, $\mathrm{T}_{\mathrm{H}} 17$ cells cultured with IL-23 were encephalitogenic (Figure 1) (McGeachy et al., 2007). This correlates with enhanced expression of IL-10 in $\mathrm{T}_{\mathrm{H}}$ 17-polarized

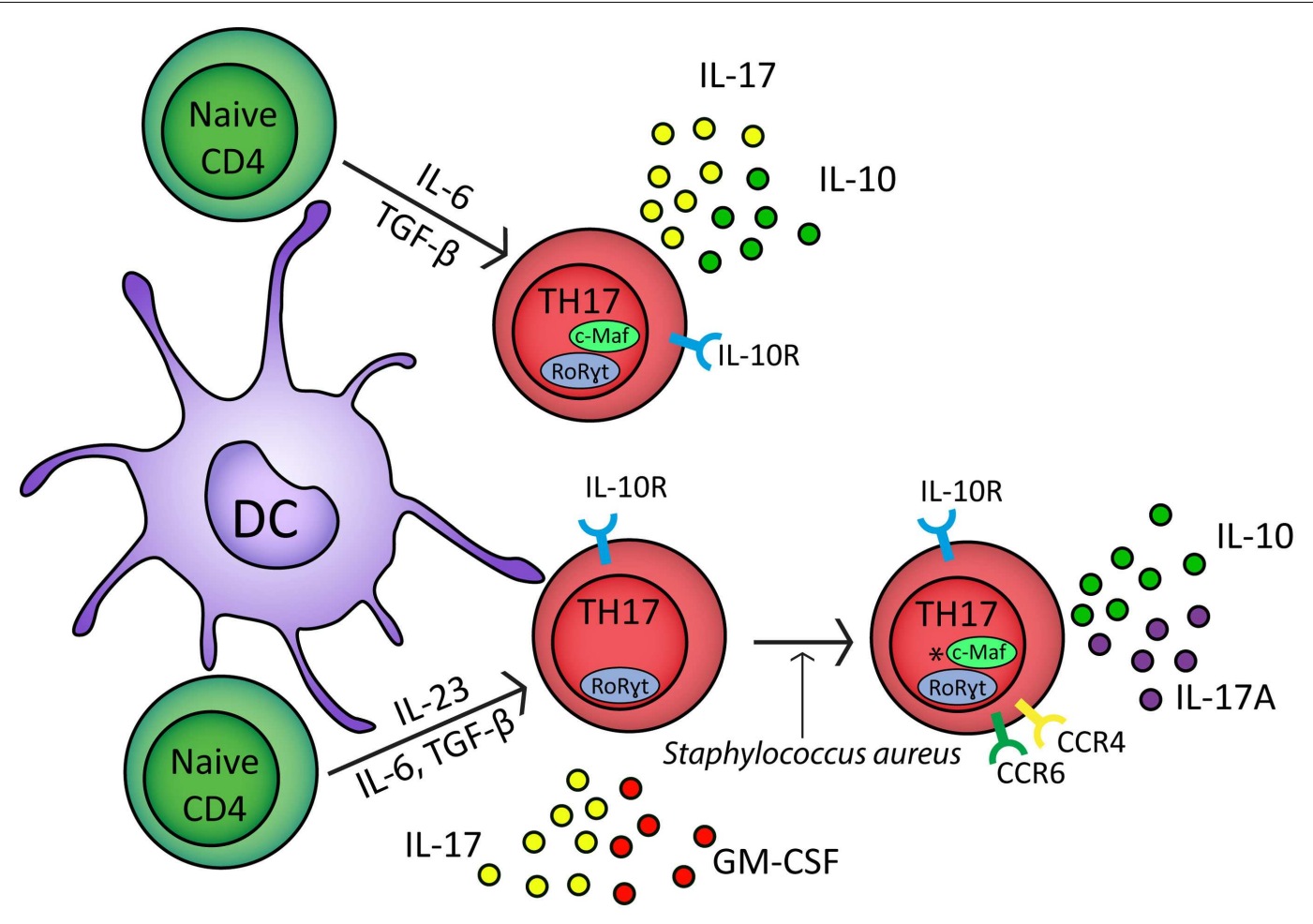

FIGURE 1 | In response to IL-6, TGF- $\beta$, and TCR stimulation naïve $\mathrm{CD}^{+}$cells upregulate RoR $\gamma \mathrm{t}$ and $\mathrm{c}-\mathrm{Maf}$ transcription factors and develop into $\mathrm{T}_{\mathrm{H}} 17$ polarized naïve $\mathrm{CD4}^{+}$cells which secrete IL-17 and IL-10 (McGeachy et al., 2007). In the presence of IL-6, TGF- $\beta$, IL-23, and TCR stimulation, naïve $\mathrm{CD} 4^{+}$cells differentiate into effector $\mathrm{T}_{H} 17$ cells which express RoRyt and secrete IL-17 and GM-CSF (McGeachy et al., 2009). In response to Staphylococcus aureus, effector $T_{H} 17$ cells develop into CCR6 ${ }^{+} \mathrm{CCR}^{+}$memory cells which secrete IL-17A and IL-10; *however, it is unclear if c-Maf regulates IL-10 in these cells (Metzler and Wraith, 1993; Zielinski et al., 2012). $T_{H} 17$ cells express the IL-10 receptor and can therefore self-regulate (Stumhofer et al., 2007; Huber et al., 2011). IL-1 $\beta$ can down regulate IL-10 expression from both $\mathrm{T}_{\mathrm{H}} 17$ polarized naïve CD4 ${ }^{+}$cells and $\mathrm{T}_{\mathrm{H}} 17$ memory cells (Zielinski et al., 2012). 
$\mathrm{CD}^{+} \mathrm{T}$ cells cultured in the absence of IL-23 (McGeachy et al., 2007).

Interleukin-10-secreting $\mathrm{T}_{\mathrm{H}}$ 17-polarized $\mathrm{CD}^{+} \mathrm{T}$ cells have also been observed with defined pathogen specificity. Upon restimulation in vitro, human Staphylococcus aureus-specific $\mathrm{T}_{\mathrm{H}} 17$ cells secreted IL-10 in combination with IL-17A (Figure 1) (Zielinski et al., 2012). In contrast, Candida albicans-specific $\mathrm{T}_{\mathrm{H}} 17$ polarized $\mathrm{CD}^{+} \mathrm{T}$ cells did not secrete IL-10 and instead secreted IFN- $\gamma$ concomitant with IL-17A (Zielinski et al., 2012). IL-10 secretion by naïve $\mathrm{CD} 4^{+} \mathrm{T}$ cells polarized toward IL-17 secretion or by $\mathrm{CCR}^{+}{ }^{+} \mathrm{CCR} 4^{+}$memory $\mathrm{T}_{\mathrm{H}} 17$ cells was inhibited by IL- $1 \beta$ (Figure 1) (Zielinski et al., 2012). Cryopyrin associated periodic syndrome (CAPS) is an autoinflammatory disease characterized by excessive production of IL-1 $\beta$ (77). IL-10 production is significantly inhibited in $\mathrm{T}_{\mathrm{H}} 17$ cell clones from CAPS patients but in vivo administration of Anakinra, an IL-1R1 antagonist, restores IL-10 secretion by IL-17A ${ }^{+}$T cell clones (Jacobs and Ciaccio, 2010; Zielinski et al., 2012). Together these studies suggest that IL-10 production by IL-17A-secreting $\mathrm{CD} 4^{+} \mathrm{T}$ cells may refine $\mathrm{T}_{\mathrm{H}} 17$ responses to target them toward specific pathogens. In addition, these results show that the lack of IL-10 secretion by $\mathrm{T}_{\mathrm{H}} 17$ cells is associated with autoinflammatory conditions, highlighting the importance of effector T cell-derived IL-10 in immune regulation.

\section{TH1-DERIVED IL-10 IN THE REGULATION OF TH1 RESPONSES}

$\mathrm{T}_{\mathrm{H}} 1$ cells, characterized by expression of the transcription factor T-bet and secretion of IFN- $\gamma$, play a central role in the clearance of intracellular pathogens (Romagnani, 1996). However, they are also responsible for mediating immune pathology and autoimmune disease in a number of settings. For example, the intracellular protozoan parasite $T$. gondii elicits an IL-12-dependent $\mathrm{T}_{\mathrm{H}} 1$ response which is important for controlling its replication in infected mice (Gazzinelli et al., 1994). In IL-10-deficient mice, this $\mathrm{T}_{\mathrm{H}} 1$ response is exacerbated and results in severe cytokineassociated immunopathology and mice succumb to disease even though parasitic growth is effectively restricted (Gazzinelli et al., 1996). This immune pathology is characterized by increased secretion of $\mathrm{T}_{\mathrm{H}} 1$ cytokines, expression of acute inflammatory markers and necrotic tissue damage (Gazzinelli et al., 1996). A dysregulated $\mathrm{T}_{\mathrm{H}} 1$ response and subsequent tissue damage are also observed in IL-10-deficient mice following infection with other pathogens, including Leishmania major (Anderson et al., 2007), Trypanosoma cruzi (Abrahamsohn and Coffman, 1996; Hunter et al., 1997), Plasmodium chabaudi (Linke et al., 1996), Listeria monocytogenes (Deckert et al., 2001), murine cytomegalovirus (Oakley et al., 2008), and respiratory influenza virus (Sun et al., 2009). Similarly, IL-10-dependent $\mathrm{T}_{\mathrm{H}} 1$ self-regulation is essential in restraining the immune response and preventing tissue damage in models of autoimmune disease including colitis (Suri-Payer and Cantor, 2001), RA (Hata et al., 2004), neuritis (Bai et al., 1997), SLE (Beebe et al., 2002), and uveoretinitis (Rizzo et al., 1998). Conversely, $\mathrm{CD}^{+}{ }^{+} \mathrm{T}$ cells which co-secrete IFN- $\gamma$ and IL-10 can be isolated from patients with chronic infections, including Mycobacterium tuberculosis and Leishmania donovani (Gerosa et al., 1999; Kemp et al., 1999; Boussiotis et al., 2000). This suggests that IL-10 secretion by $\mathrm{T}_{\mathrm{H}} 1$-like cells regulates the anti-pathogen response and prevents clearance.
Interleukin-10-secreting, $\mathrm{T}_{\mathrm{H}} 1$-like cells can be induced in experimental models by repeated or chronic administration of antigen (Figure 2) (Metzler and Wraith, 1993; Gabryšová et al., 2009; Gabryšová and Wraith, 2010). In the Tg4 TCR-transgenic mouse model, repeated intranasal (i.n.) administration of analogs of the Ac1-9 peptide of myelin basic protein drives the generation of FoxP3 ${ }^{-}$T-bet $^{+}$IL-10-secreting $\mathrm{CD}^{+}{ }^{+} \mathrm{T}$ cells which protect animals from EAE (Rogge et al., 1997; Burkhart et al., 1999; Gabryšová et al., 2009). IL-10 secreted by T-bet ${ }^{+} \mathrm{CD}^{+}{ }^{+} \mathrm{T}$ cells modulates DC function, inducing downregulation of MHC class II, the co-stimulatory molecules CD80, CD86, and CD40, and the $\mathrm{T}_{\mathrm{H}}$ 1-promoting cytokine IL-12 (Moore et al., 2001; Gabryšová et al., 2009). This renders DCs from Tg4 mice treated repeatedly with the Ac1-9 analog less effective than DCs from non-peptide treated mice at priming naïve $\mathrm{CD} 4^{+} \mathrm{T}$ cells and promoting $\mathrm{T}_{\mathrm{H}} 1$ differentiation (Gabryšová et al., 2009). This represents a therapeutically exploitable negative feedback loop for the attenuation of IFN- $\gamma$-driven inflammatory responses (Figure 2).

Although IL-10-mediated negative feedback regulation of $\mathrm{CD}^{+}$effector lymphocyte responses undoubtedly evolved to prevent collateral tissue damage during immune responses to pathogens, it can also prevent successful clearance of microorganisms and lead to prolonged chronic infection. For example, in mice infected with L. major, CD4 ${ }^{+}$Foxp $3^{-}$IL-10-secreting cells are associated with development of contained, chronic, non-healing lesions (Anderson et al., 2007). Elevated CD4 ${ }^{+}$T cell-derived IL-10 also correlates with an inability to effectively clear $M$. tuberculosis (Redford et al., 2011), L. monocytogenes (Dai et al., 1997), Mycobacterium leprae (Sieling et al., 1993), and transformed cells, for example squamous cell carcinomas (Kim et al., 1995).

\section{TH2-DERIVED IL-10 IN THE REGULATION OF TH2 RESPONSES}

The cytokines IL-4, IL-5, and IL-13, secreted by $\mathrm{T}_{\mathrm{H}} 2$ cells, provide protective immunity in the context of parasite infection (Korenaga et al., 1991; Urban et al., 1991), but also initiate, amplify, and prolong allergic responses by enhancing production of IgE and are responsible for recruitment, expansion, and differentiation of eosinophils and mast cells (Robinson et al., 1992; Romagnani, 1994; Umetsu and DeKruyff, 1997, 1999; Northrop et al., 2006). Early studies of experimental $\mathrm{T}_{\mathrm{H}}$ 2-inducing parasitic infections, including Trichuris muris and T. cruzii demonstrated a key role for IL-10 in preventing a lethal T cell response (Silva et al., 1992; Barbosa de Oliveira et al., 1996; Schopf et al., 2002). The exaggerated cytokine response observed in IL-10-deficient mice was initially assumed to be due to a requirement for IL-10 in antagonizing deleterious $\mathrm{T}_{\mathrm{H}} 1$ responses (Silva et al., 1992; Barbosa de Oliveira et al., 1996; Schopf et al., 2002). More recently, it has become clear that $\mathrm{T}_{\mathrm{H}}$ 2-derived IL-10 is also associated with downregulation of IL-4 and IL-13 during allergic responses (Grünig et al., 1997; Jutel et al., 2003; Akdis et al., 2004). In a mouse model of allergic bronchopulmonary aspergillosis, IL-10 is crucial in restraining $\mathrm{T}_{\mathrm{H}} 2$ responses (Grünig et al., 1997). After repeated inhalation of Aspergillus fumigatus allergens, lung cells and broncho-alveolar lavage (BAL) fluid from IL-10-knockout mice produced higher levels of IL-4, IL-5, and IFN- $\gamma$, leading to exaggerated airway inflammation (Grünig et al., 1997). In addition, alveolar macrophages isolated from asthmatic patients secrete lower levels of IL-10 compared to those from 


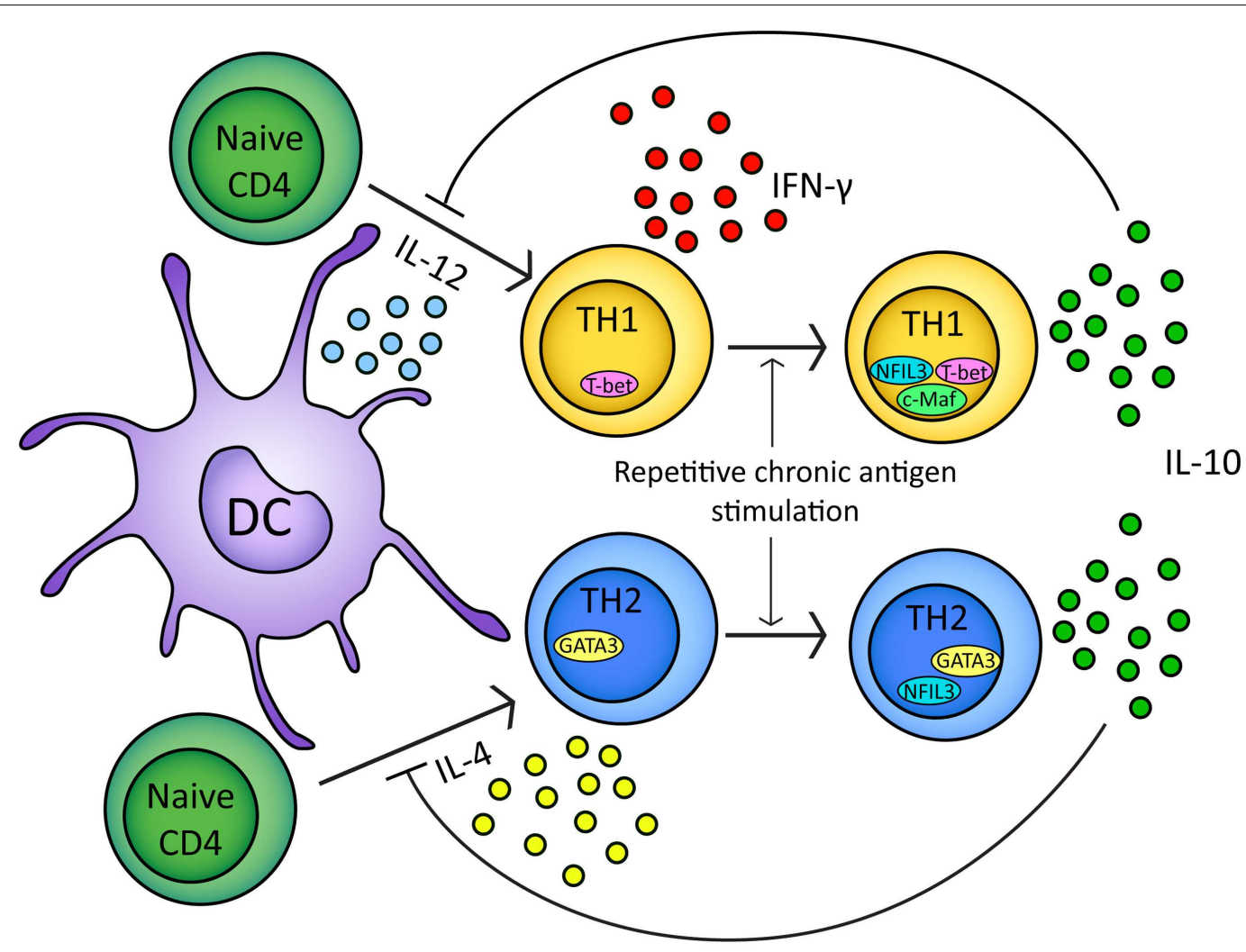

FIGURE 2 | In response to either IL-12 or IL-4 and TCR stimulation naïve $\mathrm{CD4}^{+} \mathrm{T}$ cells will upregulate T-bet or GATA3 transcription factors respectively. Differentiation of naïve $C D 4^{+} t$ cells into $T_{H} 1 / T_{H} 2$ lineages is based on T-bet/GATA3 transcription factor expression (Ouyang et al., 2000; Lucas et al., 2003). Upon repeated chronic TCR stimulation $T_{H} 1$ and $T_{H} 2$ cells express IL-10 (Gabryšová et al., 2009; Xu et al., 2009). In $T_{H} 1$ cells, IL-10 expression is regulated by NFIL3 and correlates with c-Maf expression (Kim et al., 1999; Saraiva et al., 2009). In $\mathrm{T}_{\mathrm{H}} 2$ cells, IL-10 expression is regulated by NFIL3 (Motomura et al. 2011). IL-10 secreted by $T_{H} 1 / T_{H} 2$ cells can inhibit further naïve CD4+ differentiation by inhibiting IL-12/IL-4 and DC function (Moore et al., 2001; Taylor et al., 2007, 2009). non-asthmatics (Borish, 1998; John et al., 1998). In healthy bee keepers, regular bee venom exposure elicits a regulatory response characterized by antigen-specific IL-10 secretion and a reduction in IL-4 and IL-13 production over the course of the bee season (Meiler et al., 2008). TGF- $\beta$ appears to play a minor role in the effect and little increase in FoxP3 expression is observed after bee venom exposure, suggesting that repeatedly activated allergenspecific $\mathrm{T}$ cells, and not FoxP3 ${ }^{+}$Tregs induced de novo, are the source of regulatory IL-10 (Meiler et al., 2008).

In mouse models of allergy, it is clear that IL-10 plays an important role in mediating successful antigen-specific therapeutic tolerance. For example, intranasal administration of peptide derived from OVA can reduce symptoms of $\mathrm{T}_{\mathrm{H}} 2$-driven OVA/alum-induced airway hypersensitivity (AHR) (Akbari et al., 2001). Protection from AHR is associated with induction of IL10 -secreting pulmonary DCs with capacity to induce IL-4 and IL-10-secreting OVA-specific CD4 ${ }^{+} \mathrm{T}$ cells in vitro (Akbari et al., 2001). In addition, adoptive transfer of DCs from i.n. OVA treated mice to naïve animals induced OVA-specific $\mathrm{CD}^{+}{ }^{+} \mathrm{T}$ cell unresponsiveness in recipients. Transfer of IL-10-deficient DCs does not induce tolerance in recipient mice (Akbari et al., 2001). Similarly, neutralization of IL-10 during tolerance induction results in elevated OVA-specific IgE production and negates the protective effect of OVA administration (Vissers et al., 2004). Successful allergen-specific immunotherapy (SIT) in man, for example in the treatment of grass pollen or house dust mite allergies, correlates with generation of IL-10-secreting CD4 ${ }^{+} \mathrm{T}$ cells (Francis et al., 2003; Jutel et al., 2003). IL-10 limits $\mathrm{T}_{\mathrm{H}} 2$ responses by downregulation of IL-4, inhibition of antigen presentation by MHC class II on DCs, and suppression of co-stimulatory molecule expression including CD28, ICOS, and CD2 (Taylor et al., $2007,2009)$. This is mediated via src homology phosphatase (SHP)-1 in naïve $\mathrm{CD}^{+} \mathrm{T}$ cells, suggesting that IL-10 can regulate effector responses and also prevent the differentiation of $\mathrm{T}_{\mathrm{H}} 2$ cells from naïve $\mathrm{CD}^{+} \mathrm{T}$ cells (Figure 2) (Taylor et al., 2007).

\section{TRANSCRIPTIONAL REGULATION OF IL-10 IN $\mathrm{T}_{H} 1, \mathrm{~T}_{H} 2, \mathrm{~T}_{H} 17$, AND Tr1 CELLS}

As described above, IL-10 can be secreted by different CD4 ${ }^{+} \mathrm{T}$ cell types, each characterized by a distinct developmental program and hallmark transcription factors. However, some signaling pathways and transcription factors required to induce IL-10 expression are shared between $\mathrm{CD}^{+}{ }^{+}$effector T cell subsets. The group of transcription factors regulating IL-10 transcription in all cell types has been reviewed recently (Saraiva and O'Garra, 2010) and we will 
focus on IL-10 transcriptional regulation in $\mathrm{T}_{\mathrm{H}} 1, \mathrm{~T}_{\mathrm{H}} 2, \mathrm{~T}_{\mathrm{H}} 17$, and Tr1 cells.

ERK1 and ERK2 activation is required for IL-10 expression in $\mathrm{T}_{\mathrm{H}} 1, \mathrm{~T}_{\mathrm{H}} 2$, and $\mathrm{T}_{\mathrm{H}} 17$ cells (Saraiva et al., 2009). In $\mathrm{CD}^{+}$ $\mathrm{T}$ cells, the strength of signaling through the TCR is proportional to ERK1 and ERK2 activation and thus to IL-10 expression (Saraiva et al., 2009). Specifically, in Th1 cells high-level TCR stimulation leads to enhanced and prolonged ERK1 and ERK2 phosphorylation which, in combination with IL-12-driven signaling through STAT4, promotes induction of IL-10 (Saraiva et al., 2009).

Recently differentiated $\mathrm{T}_{\mathrm{H}} 1$ cells do not secrete IL-10 and have an IL-10 promoter which is inaccessible to DNase 1 and thus not permissive for transcription (Im et al., 2004). In contrast, fully differentiated $\mathrm{T}_{\mathrm{H}} 2$ cells have an open, euchromatic IL-10 promoter (Im et al., 2004). In addition, histone modifications which correlate with active gene expression; histone 3 lysine 4 dimethylation (H3K4me2) and histone 4 acetylation (AcH4) are associated with the IL-10 promoter in effector $\mathrm{T}_{\mathrm{H}} 2$ cells but not $\mathrm{T}_{\mathrm{H}} 1$ cells (Im et al., 2004).

$\mathrm{T}_{\mathrm{H}} 2$ effector differentiation and function is classically described as being dependent upon STAT6-induced GATA3 expression (Shoemaker et al., 2006). Although STAT6-induced GATA3 is thought to mediate the epigenetic changes that result in an open IL-10 locus in $\mathrm{T}_{\mathrm{H}} 2$ cells, both proteins are dispensable for IL10 secretion in mature $\mathrm{T}_{\mathrm{H}} 2$-polarized $\mathrm{CD}^{+} \mathrm{T}$ cells (Figure 3) (Ouyang et al., 2000; Shoemaker et al., 2006). Similarly, c-Maf is another transcription factor originally associated with $\mathrm{T}_{\mathrm{H}} 2$ cells although it is not required for IL-10 production in $\mathrm{CD} 4^{+} \mathrm{T}$ cells cultured under $\mathrm{T}_{\mathrm{H}} 2$-polarizing culture conditions (Kim et al., 1999). Interestingly, in non-polarizing culture conditions, where cells secreted IFN- $\gamma$, IL-10 production was dependent on c-Maf expression (Kim et al., 1999). Indeed, c-Maf binds to the Mafrecognition element within the IL-10 promoter and is required for IL-10 expression in $\operatorname{Tr} 1, \mathrm{~T}_{\mathrm{H}} 17$, and possibly $\mathrm{T}_{\mathrm{H}} 1$ cells (Figure 3 ) (Kim et al., 1999; Pot et al., 2009; Saraiva et al., 2009; Xu et al.,

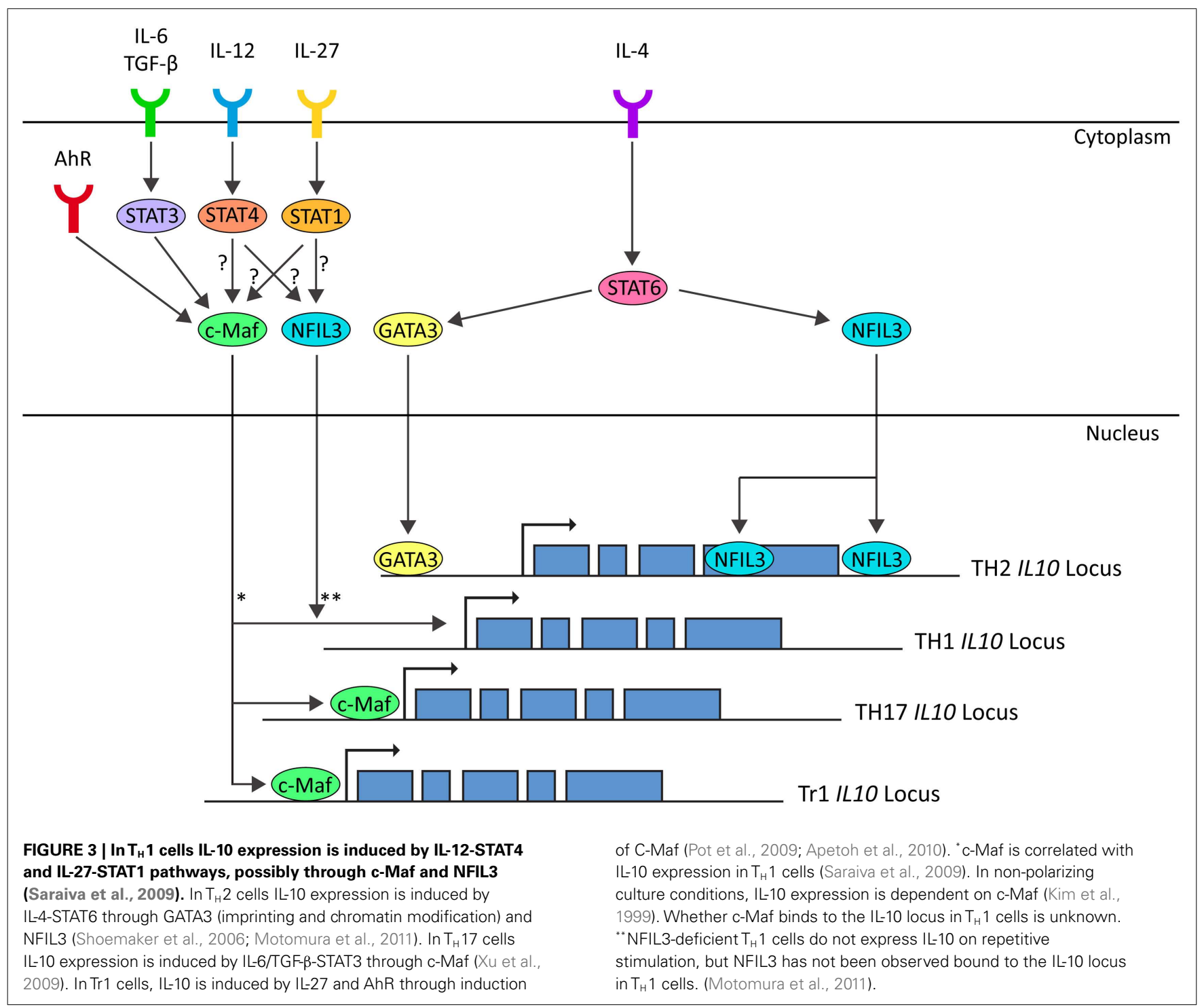


2009). Although c-Maf is required for IL-10 secretion by a variety of $\mathrm{CD}^{+}{ }^{+} \mathrm{T}$ cell lineages, differences in the pathways which evoke c-Maf expression reflect the diversity of the $\mathrm{T}_{\mathrm{H}}$ lineages. In $\mathrm{T}_{\mathrm{H}} 1$ cells, IL-10 expression can be induced by both IL-27 via both STAT1 and STAT3 and IL-12 via STAT4 (Stumhofer et al., 2007; Saraiva et al., 2009). In Tr1 cells, IL-27 induces expression of c-Maf and AhR, presumably through STAT1, which cooperatively promote IL-10 expression (Figure 3) (Pot et al., 2009; Apetoh et al., 2010). In $T_{H} 17$ cells, c-Maf expression is induced by the synergistic action of TGF- $\beta$ and IL- 6 via STAT3 and, in contrast to the observations in $\mathrm{T}_{\mathrm{H}} 1$ cells, the activation of STAT1 is antagonistic for c-Maf-induced IL-10 expression in $\mathrm{T}_{\mathrm{H}} 17$-polarized CD4 ${ }^{+} \mathrm{T}$ cells (Figure 3) (Xu et al., 2009). Which pathway drives c-Maf expression may depend on specific conditions such as the affinity and dose of antigen (Saraiva et al., 2009). For example, in $\mathrm{T}_{\mathrm{H}} 1$ cells, IL-12-mediated STAT4 signaling only promotes IL-10 production in combination with high-level TCR stimulation (Saraiva et al., 2009) whereas at lower levels of TCR stimulation, the same stimulus induces the development of IFN- $\gamma$-secreting $\mathrm{T}_{\mathrm{H}} 1$ cells that do not express IL-10 (Morinobu et al., 2002; Lucas et al., 2003; Saraiva et al., 2009).

The basic leucine zipper transcription factor nuclear factor IL3-regulated (NFIL3 or E4BP4) has recently been shown to play a role in a range of immunological processes (reviewed in Male et al., 2012). NFIL3-deficient $\mathrm{T}_{\mathrm{H}} 2$ cells and FoxP $3^{+}$Tregs are defective in IL-10 secretion and it is also required for the upregulation of IL-10 in repeatedly stimulated $\mathrm{T}_{\mathrm{H}} 1$ cells (Figure 3) (Chang et al., 2007; Motomura et al., 2011). NFIL3 does not bind to the IL10 promoter, but rather to introns within the coding region of the locus (Motomura et al., 2011). In NFIL3-deficient $\mathrm{T}_{\mathrm{H}} 2$ cells, these regions are heterochromatic and inaccessible, suggesting that NFIL3 may play a role in remodeling the IL10 locus to permit transcription (Motomura et al., 2011). Upregulation of NFIL3 in $\mathrm{T}_{\mathrm{H}} 2$ cells is dependent on IL-4 and STAT6, even upon GATA3 overexpression (Kubo and Motomura, 2012). Further work is required to understand the pathways leading to induction of NFIL3 expression in repeatedly stimulated $\mathrm{T}_{\mathrm{H}} 1$ cells and to confirm that NFIL3 is a universal regulator of IL-10 expression in $\mathrm{CD}^{+} \mathrm{T}$ cells.

\section{CLINICAL APPLICATIONS AND FUTURE PROSPECTS}

As described above, the ratio of secreted IL-10 to the secretion of the relevant effector cytokine (IFN- $\gamma$, IL-4, or IL-17) can dictate the outcome of a polarized $\mathrm{CD} 4{ }^{+} \mathrm{T}$ cell response and, therefore, the likelihood of an effective immune response and the potential for tissue damage, through hyper- or hypo-immune activation. These observations have made IL-10 an attractive therapeutic target for intervention in a wide range of human conditions including autoimmunity, cancer, and persistent infection (O'Garra et al., 2008).

Inhaled glucocorticoids are at present the treatment of choice for asthma and severe allergic conditions. In addition to the effects of corticosteroids, including dexamethosone, on IL-10 expression in vitro, glucocorticoid administration to asthmatic patients enhances IL-10 production concomitant with a reduction in $\mathrm{T}_{\mathrm{H}} 1$ and $\mathrm{T}_{\mathrm{H}} 2$ effector cytokines (John et al., 1998; Richards et al., 2000). Treatment with inhaled steroids is also accompanied by expansion of $\mathrm{CD} 4{ }^{+} \mathrm{CD} 25^{+}$Treg populations and upregulation of Foxp3 gene expression in CD4 ${ }^{+} \mathrm{T}$ cells isolated from PBMCs (Karagiannidis et al., 2004). Furthermore, failure to upregulate IL-10 in response to steroid exposure correlates with steroid resistant disease (Hawrylowicz et al., 2002; Xystrakis et al., 2006). This further illustrates the importance of steroid-induced IL-10 in the treatment of asthma and atopy.

Several pre-clinical cancer models suggest that IL-10 acts as a negative mediator of anti-tumor immunity (Halak et al., 1999; Garcia-Hernandez et al., 2002; Yang and Lattime, 2003). These are further supported by human studies in Hodgkin's lymphoma, B cell lymphoma, melanoma, and hepatocellular carcinoma, where elevated serum IL-10 levels correlate with poor survival (Bohlen et al., 2000; Chau et al., 2000; Nemunaitis et al., 2001; LechMaranda et al., 2004). These observations have supported proposals that blockade of IL-10R signaling may be a beneficial adjunct therapy in the oncology clinic. However, the pleiotropic role of IL-10 has resulted in several paradoxical observations. For example, studies investigating IL-10 levels in non-small cell lung cancer observed that higher IL-10 expression correlated with better survival (Gonzalez-Aragoneses et al., 2007). In addition, overexpression of IL-10 within tumors, in murine carcinoma and melanoma models, results in loss of tumorigenicity accompanied by an enhanced lymphocyte response (Giovarelli et al., 1995; Gerard et al., 1996; Zheng et al., 1996; Adris et al., 1999). IL-10mediated prevention of tumor growth is dependent on T cells and/or NK cells as these effects are abrogated in immunodeficient mice (Giovarelli et al., 1995; Zheng et al., 1996). In agreement with these reports, IL-10 can stimulate NK cell and alloreactive CD8 ${ }^{+}$ $\mathrm{T}$ cell responses in vitro and in vivo and may have the same effect in certain cancers or subsets of patients (Groux et al., 1998, 1999; Cai et al., 1999; Micallef et al., 1999; Lauw et al., 2000).

Systemic administration of recombinant IL-10 has been trialed in patients with psoriasis and Crohn's disease and for the alleviation of post-operative inflammation (Colombel et al., 2001; Reich et al., 2001; O'Garra et al., 2008). This has been generally tolerated at moderate doses and has provided some clinical improvement in psoriasis patients, associated with a reduction in $\mathrm{T}_{\mathrm{H}} 1$ cytokines (Reich et al., 2001). However, side effects including fever and headaches were observed and, in Crohn's disease patients, IL-10 administration led to elevated serum levels of IFN$\gamma$ and no improvement in disease symptoms (Tilg et al., 2002). Simultaneous administration of IL-10 and LPS in healthy volunteers similarly led to an exaggerated $\mathrm{T}_{\mathrm{H}} 1$-like response compared to LPS alone (Lauw et al., 2000). This reinforced the potential for IL-10 to play a proinflammatory role, particularly at high doses, and made the use of recombinant IL-10 as a therapeutic approach unfavorable.

The failure of systemic IL-10 administration to ameliorate $\mathrm{T}_{\mathrm{H}} 1$ mediated pathologies highlights the importance of refinement and specificity in the design of immunomodulatory therapy. Targeting IL-10-inducing interventions to a particular anatomical site, or to cells with defined antigen specificity, may prove far more effective than non-targeted therapies. For example, although systemic administration of IL-10 can only partially ameliorate EAE symptoms in mice (Cannella et al., 1996; Nagelkerken et al., 1997), targeted expression of IL-10 in either CD2 or MHC-II-expressing cells completely abrogates disease (Bettelli et al., 1998; Cua et al., 
1999). Similarly, expression of IL-10 in the central nervous system (CNS) rendered mice resistant to EAE whereas the cytokine, introduced systemically using the same expression vector, provided little benefit (Cua et al., 2001). Interestingly, orally administered IL-10, given with low-dose MBP peptide, prevented EAE (Slavin et al., 2001). Expression of IL-10 under control of the IL-2 promoter in proteolipid protein (PLP)-specific CD4 ${ }^{+} \mathrm{T}$ cells renders them able to both prevent and treat EAE thereby demonstrating the efficacy of antigen-specific IL-10 induction (Mathisen et al., 1997). Similarly, studies of IL-10-secreting cell-based therapies have reinforced the advantage of antigen specificity for effective immunotherapy (Barrat et al., 2002). As described above, IL-10secreting $\mathrm{CD} 4^{+} \mathrm{T}$ cells can be derived from naïve $\mathrm{T}$ cells following in vitro treatment with Dex and VitD3 (Barrat et al., 2002). In theory, this would provide a source of cells that could be used therapeutically. Using OVA-specific TCR-transgenic (DO11.10) T cells, it was demonstrated that, although IL-10-secreting CD4 ${ }^{+} \mathrm{T}$ cells can be generated using anti-CD3 and -CD28 polyclonal stimulation, antigen-specific stimulation is required in vivo for IL-10secreting cells to prevent EAE following adoptive transfer (Barrat et al., 2002). This makes antigen-SIT a very attractive approach to realize the potential of IL-10 modulation in the treatment of autoimmune diseases.

Autoantigen- and allergen-SIT aim to restore appropriate immune responses to innocuous antigens while avoiding systemic immune suppression thus preserving host-protective immunity (reviewed in Miller et al., 2007; Sabatos-Peyton et al., 2010). A variety of strategies have emerged; some attempt to induce antigenspecific FoxP3 ${ }^{+}$pTregs, others to induce a "switch" between $\mathrm{T}_{\mathrm{H}} 1$ and $\mathrm{T}_{\mathrm{H}} 2$-dominated immune responses or to force effector $\mathrm{CD}_{4}{ }^{+}$ T cells toward a terminally differentiated, IL-10-secreting phenotype (Miller et al., 2007; Sabatos-Peyton et al., 2010). Regardless of the cellular mechanisms underlying the SIT, successful therapies are almost always associated with an increase in specific, antigen-induced IL-10 (Miller et al., 2007; O'Garra et al., 2008; Sabatos-Peyton et al., 2010). Antigen-SIT has proven effective in many pre-clinical models of autoimmune disease, for example EAE and the NOD diabetes model (Metzler and Wraith, 1993; Brocke et al., 1996; Tian et al., 1996; Burkhart et al., 1999; Shoda et al., 2005; Gabryšová et al., 2009; Gabryšová and Wraith, 2010; Schall et al., 2012). Translation of these therapies into the clinic has shown some efficacy in treatment of MS (Warren et al., 2006), RA (Prakken et al., 2004), SLE (Muller et al., 2008), and T1D (Thrower et al., 2009; Hjorth et al., 2011; Ludvigsson et al., 2012). For example, in a phase 1 clinical trial in T1D patients using an epitope of proinsulin (C19-A3), treatment resulted in increased serum IL-10 levels and improved glycemic control in the group which received

\section{REFERENCES}

Abrahamsohn, I. A., and Coffman, R. L. (1996). Trypanosoma cruzi:IL-10, TNF, IFN- $\gamma$, and IL-12 regulate innate and acquired immunity to infection. Exp. Parasitol. 84, 231-244. doi:10.1006/expr.1996.0109

Adris, S., Klein, S., Jasnis, M., Chuluyan, E., Ledda, M., Bravo, A., et al. (1999). IL-10 expression by CT26

$10 \mu \mathrm{g}$ of peptide (Thrower et al., 2009). Interestingly, a higher dose of $100 \mu \mathrm{g}$ did not show any beneficial clinical effect and no increase in serum IL-10 (Thrower et al., 2009).

These studies demonstrate that, when appropriately designed, SIT is safe in man and has great potential in treating a wide range of autoimmune and allergic diseases. However, further research is required to determine suitable routes of administration and to refine dosing strategies. Inappropriate antigen dosing, in particular, can lead to hypersensitivity reactions or to a lack of efficacy (Bielekova et al., 2000; Kappos et al., 2000). Administration of an escalating series of antigen doses has been widely employed in the field of allergen-SIT and this approach being increasingly adopted in autoantigen-SIT (Sabatos-Peyton et al., 2010).

In many autoimmune conditions, the antigen and immunodominant epitopes are uncharacterized, and where they are characterized, epitope spreading can lead to polyantigenic responses within a single patient (Miller et al., 2007; Sabatos-Peyton et al., 2010). This provides further challenges for the successful translation of SIT from (often monoclonal, TCR-transgenic) animal models to heterogenous groups of patients. Clearly, successful translation of this approach will rely on the ability of a therapeutic strategy to induce "bystander suppression" whereby T cells specific for epitopes within antigen A are capable of suppressing the response of T cells specific for antigens $B, C$, D, etc. within the same tissue. The fact that IL-10 suppresses co-stimulatory molecule expression by APC explains why IL-10 treated APC can mediate bystander suppression and why strategies designed to induce IL-10 are required for effective SIT. It will also be essential to widen our understanding of the molecular mechanisms underlying successful SIT, enabling development of adjunct therapies and adjuvants to bolster efficacy, improve safety, and aid maintenance of long-term tolerance.

In conclusion, IL-10 plays an essential and highly complex role in the modulation of adaptive immune responses. The pleiotropic nature of IL-10 has made translating the potential benefit of IL-10modulating therapies into the clinic difficult; however, strategies designed to focus IL-10 expression onto antigen-specific $\mathrm{T}$ cells, including SIT for allergic and autoimmune diseases, have shown promising early results.

\section{ACKNOWLEDGMENTS}

The authors wish to thank members of the Wraith laboratory for discussions and critical reading of this manuscript. Work in the Wraith laboratory is supported by the Wellcome Trust (091074/z/09/z) and the MRC (MR/K007654/1) and GJB is supported by a Wellcome Trust $\mathrm{PhD}$ studentship (086779/Z/08/A).

Nat. Immunol. 2, 725-731. doi:10.1038/90667

Akdis, M., Verhagen, J., Taylor, A., Karamloo, F., Karagiannidis, C., Crameri, R., et al. (2004). Immune responses in healthy and allergic individuals are characterized by a fine balance between allergenspecific $\mathrm{T}$ regulatory 1 and $\mathrm{T}$ helper 2 cells. J. Exp. Med. 199, 1567-1575. doi:10.1084/jem.20032058
Allan, D. S. J., Colonna, M., Lanier, L. L., Churakova, T. D., Abrams, J. S., Ellis, S. A., et al. (1999). Tetrameric complexes of human histocompatibility leukocyte antigen (HLA)-G bind to peripheral blood myelomonocytic cells. J. Exp. Med. 189, 1149-1156. doi:10.1084/jem.189.7.1149

Anderson, C. F., Oukka, M., Kuchroo, V. J., and Sacks, D. (2007). CD4+CD25-Foxp3- Th1 
cells are the source of IL-10mediated immune suppression in chronic cutaneous leishmaniasis. J. Exp. Med. 204, 285-297. doi:10.1084/jem.20061886

Apetoh, L., Quintana, F. J., Pot, C., Joller, N., Xiao, S., Kumar, D., et al. (2010). The aryl hydrocarbon receptor interacts with c-Maf to promote the differentiation of type 1 regulatory $\mathrm{T}$ cells induced by IL-27. Nat. Immunol. 11, 854-861. doi:10.1038/ni.1912

Astier, A. L., Meiffren, G., Freeman, S., and Hafler, D. A. (2006). Alterations in CD46-mediated $\operatorname{Tr} 1$ regulatory $\mathrm{T}$ cells in patients with multiple sclerosis. J. Clin. Invest. 116, 3252-3257. doi:10.1172/jci29251

Awasthi, A., Carrier, Y., Peron, J. P., Bettelli, E., Kamanaka, M., Flavell, R. A., et al. (2007). A dominant function for interleukin 27 in generating interleukin 10-producing antiinflammatory T cells. Nat. Immunol. 8, 1380-1389. doi:10.1038/ ni1541

Bai, X. F., Zhu, J., Zhang, G. X., Kaponides, G., Höjeberg, B., van der Meide, P. H., et al. (1997). IL-10 suppresses experimental autoimmune neuritis and down-regulates TH1-type immune responses. Clin. Immunol. Immunopathol. 83, 117-126. doi:10.1006/clin.1997.4331

Barbosa de Oliveira, L. C., Curotto de Lafaille, M. A., Collet de Araujo Lima, G. M., and de Almeida Abrahamsohn, I. (1996). Antigen-specific Il-4- and IL-10-secreting CD4+ lymphocytes increase in vivo susceptibility to Trypanosoma cruzi infection. Cell. Immunol. 170, 41-53. doi:10.1006/cimm.1996.0132

Barrat, F. J., Cua, D. J., Boonstra, A., Richards, D. F., Crain, C., Savelkoul, H. F., et al. (2002). In vitro generation of interleukin 10-producing regulatory $\mathrm{CD} 4+\mathrm{T}$ cells is induced by immunosuppressive drugs and inhibited by $\mathrm{T}$ helper type 1 (Th1)- and Th2-inducing cytokines. J. Exp. Med. 195, 603-616. doi:10.1084/jem.20011629

Battaglia, M., Stabilini, A., Draghici, E., Gregori, S., Mocchetti, C., Bonifacio, E., et al. (2006). Rapamycin and interleukin-10 treatment induces $\mathrm{T}$ regulatory type 1 cells that mediate antigen-specific transplantation tolerance. Diabetes 55, 40-49. doi:10.2337/diabetes.55.01.06.db050613

Beebe, A. M., Cua, D. J., and de Waal Malefyt, R. (2002). The role of interleukin-10 in autoimmune disease: systemic lupus erythematosus (SLE) and multiple sclerosis (MS). Cytokine Growth Factor Rev. 13, 403-412. doi:10. 1016/S1359-6101(02)00025-4

Bettelli, E., Carrier, Y., Gao, W., Korn, T., Strom, T. B., Oukka, M., et al. (2006). Reciprocal developmental pathways for the generation of pathogenic effector TH17 and regulatory T cells. Nature 441, 235-238. doi:10.1038/nature04753

Bettelli, E., Prabhu Das, M., Howard, E. D., Weiner, H. L., Sobel, R. A., and Kuchroo, V. K. (1998). IL-10 is critical in the regulation of autoimmune encephalomyelitis as demonstrated by studies of IL-10- and IL4-deficient and transgenic mice. J. Immunol. 161, 3299-3306.

Bielekova, B., Goodwin, B., Richert, N., Cortese, I., Kondo, T., Afshar, G., et al. (2000). Encephalitogenic potential of the myelin basic protein peptide (amino acids 83-99) in multiple sclerosis: results of a phase II clinical trial with an altered peptide ligand. Nat. Med. 6, 1167-1175. doi:10.1038/80516

Bohlen, H., Kessler, M., Sextro, M. Diehl, V., and Tesch, H. (2000). Poor clinical outcome of patients with Hodgkin's disease and elevated interleukin-10 serum levels. Clinical significance of interleukin10 serum levels for Hodgkin's disease. Ann. Hematol. 79, 110-113. doi:10.1007/s002770050564

Borish, L. (1998). IL-10: Evolving concepts. J. Allergy Clin. Immunol. 101, 293-297. doi:10.1016/S00916749(98)70238-6

Boussiotis, V. A., Tsai, E. Y., Yunis, E. J., Thim, S., Delgado, J. C., Dascher, C. C., et al. (2000). IL-10-producing $\mathrm{T}$ cells suppress immune responses in anergic tuberculosis patients. J. Clin. Invest. 105, 1317-1325. doi:10.1172/JCI9918

Brocke, S., Gijbels, K., Allegretta, M., Ferber, I., Piercy, C., Blankensteini, T., et al. (1996). Treatment of experimental encephalomyelitis with a peptide analogue of myelin basic protein. Nature 379, 343-346. doi:10.1038/379343a0

Brunkow, M. E., Jeffery, E. W., Hjerrild, K. A., Paeper, B., Clark, L. B., Yasayko, S. A., et al. (2001). Disruption of a new forkhead/winged-helix protein, scurfin, results in the fatal lymphoproliferative disorder of the scurfy mouse. Nat. Genet. 27, 68-73. doi:10.1038/83784

Burkhart, C., Liu, G. Y., Anderton, S. M., Metzler, B., and Wraith, D. C. (1999). Peptide-induced T cell regulation of experimental autoimmune encephalomyelitis: a role for
IL-10. Int. Immunol. 11, 1625-1634. doi:10.1093/intimm/11.10.1625

Cai, G., Kastelein, R. A., and Hunter, C. A. (1999). IL-10 enhances NK cell proliferation, cytotoxicity and production of IFN-gamma when combined with IL-18. Eur. J. Immunol. 29, 2658-2665. doi:10.1002/(SICI)1521-

4141(199909)29:09<2658::AIDIMMU2658>3.3.CO;2-7

Cannella, B., Gao, Y. L., Brosnan, C., and Raine, C. S. (1996). IL-10 fails to abrogate experimental autoimmune encephalomyelitis. J. Neurosci. Res. 45, 735-746. doi:10.1002/(SICI)1097-

4547(19960915)45:6<735::AIDJNR10>3.0.CO;2-V

Cardone, J., Le Friec, G., Vantourout, P., Roberts, A., Fuchs, A., Jackson, I., et al. (2010). Complement regulator CD46 temporally regulates cytokine production by conventional and unconventional $\mathrm{T}$ cells. Nat. Immunol. 11, 862-871. doi:10.1038/ni.1917

Cedeno-Laurent, F., Opperman, M., Barthel, S. R., Kuchroo, V. K., and Dimitroff, C. J. (2012). Galectin1 triggers an immunoregulatory signature in Th cells functionally defined by IL-10 expression. J. Immunol. 188, 3127-3137. doi:10.4049/jimmunol.1103433

Chang, C. C., Ciubotariu, R., Manavalan, J. S., Yuan, J., Colovai, A. I., Piazza, F., et al. (2002). Tolerization of dendritic cells by $\mathrm{T}(\mathrm{S})$ cells: the crucial role of inhibitory receptors ILT3 and ILT4. Nat. Immunol. 3, 237-243. doi:10.1038/ni760

Chang, H. D., Helbig, C., Tykocinski, L., Kreher, S., Koeck, J., Niesner, U., et al. (2007). Expression of IL-10 in Th memory lymphocytes is conditional on IL-12 or IL-4, unless the IL-10 gene is imprinted by GATA3. Eur. J. Immunol. 37, 807-817. doi:10.1002/eji.200636385

Chau, G. Y., Wu, C. W., Lui, W. Y., Chang, T. J., Kao, H. L., Wu, L. H., et al. (2000). Serum interleukin-10 but not interleukin- 6 is related to clinical outcome in patients with resectable hepatocellular carcinoma. Ann. Surg. 231, 552-558. doi:10.1097/00000658-20000400000015

Chaudhry, A., and Rudensky, A. Y. (2013). Control of inflammation by integration of environmental cues by regulatory T cells. J. Clin. Invest. 123, 939-944. doi:10.1172/JCI57175

Chaudhry, A., Samstein, R. M., Treuting, P., Liang, Y., Pils, M. C., Heinrich, J. M., et al. (2011). Interleukin-10 signaling in regulatory $\mathrm{T}$ cells is required for suppression of Th17 cell-mediated inflammation. Immunity 34, 566-578. doi:10.1016/j.immuni.2011.03.018

Colombel, J.-F., Rutgeerts, P., Malchow, H., Jacyna, M., Nielsen, O. H., RaskMadsen, J., et al. (2001). Interleukin 10 (Tenovil) in the prevention of postoperative recurrence of Crohn's disease. Gut 49, 42-46. doi:10.1136/gut.49.1.42

Crawley, E., Kay, R., Sillibourne, J., Patel, P., Hutchinson, I., and Woo, P. (1999). Polymorphic haplotypes of the interleukin-10 5' flanking region determine variable interleukin-10 transcription and are associated with particular phenotypes of juvenile rheumatoid arthritis. Arthritis Rheum. 42, 1101-1108. doi:10.1002/15290131(199906)42:6<1101::AID-

ANR6>3.0.CO;2-Y

Cua, D. J., Groux, H., Hinton, D. R., Stohlman, S. A., and Coffman, R. L. (1999). Transgenic interleukin 10 prevents induction of experimental autoimmune encephalomyelitis. J. Exp. Med. 189, 1005-1010. doi:10.1084/jem.189.6.1005

Cua, D. J., Hutchins, B., LaFace, D. M., Stohlman, S. A., and Coffman, R. L. (2001). Central nervous system expression of IL-10 inhibits autoimmune encephalomyelitis. J. Immunol. 166, 602-608.

Curotto de Lafaille, M. A., Lino, A. C., Kutchukhidze, N., and Lafaille, J. J. (2004). CD25- T cells generate CD25+Foxp3+ regulatory t cells by peripheral expansion. J. Immunol. 173, 7259-7268.

Dai, W. J., Köhler, G., and Brombacher, F. (1997). Both innate and acquired immunity to Listeria monocytogenes infection are increased in IL-10-deficient mice. J. Immunol. 158, 2259-2267.

Deckert, M., Soltek, S., Geginat, G., Lutjen, S., Montesinos-Rongen, M., Hof, H., et al. (2001). Endogenous interleukin-10 is required for prevention of a hyperinflammatory intracerebral immune response in Listeria monocytogenes meningoencephalitis. Infect. Immun. 69, 4561-4571. doi:10.1128/IAI.69.7. 4561-4571.2001

Fillatreau, S., Sweenie, C. H., McGeachy, M. J., Gray, D., and Anderton, S. M. (2002). B cells regulate autoimmunity by provision of IL10. Nat. Immunol. 3, 944-950. doi:10.1038/ni833

Fiorentino, D. F., Bond, M. W., and Mosmann, T. R. (1989). Two types of mouse $\mathrm{T}$ helper cell. IV. Th2 clones secrete a factor that 
inhibits cytokine production by Th1 clones. J. Exp. Med. 170, 2081-2095. doi:10.1084/jem.170.6.2081

Fontenot, J. D., Gavin, M. A., and Rudensky, A. Y. (2003). Foxp3 programs the development and function of $\mathrm{CD} 4+\mathrm{CD} 25+$ regulatory $\mathrm{T}$ cells. Nat. Immunol. 4, 330-336. doi:10.1038/ni904

Francis, J. N., Till, S. J., and Durham, S. R. (2003). Induction of IL$10+\mathrm{CD} 4+\mathrm{CD} 25+\mathrm{T}$ cells by grass pollen immunotherapy. J. Allergy Clin. Immunol. 111, 1255-1261. doi:10.1067/mai.2003.1570

Gabryšová, L., Nicolson, K. S., Streeter, H. B., Verhagen, J., Sabatos-Peyton, C. A., Morgan, D. J., et al. (2009). Negative feedback control of the autoimmune response through antigen-induced differentiation of IL-10-secreting Th1 cells. J. Exp. Med. 206, 1755-1767. doi:10.1084/jem.20082118

Gabryšová, L., and Wraith, D. C. (2010). Antigenic strength controls the generation of antigen-specific IL-10-secreting $\mathrm{T}$ regulatory cells. Eur. J. Immunol. 40, 1386-1395. doi:10.1002/eji.200940151

Gagliani, N., Magnani, C. F., Huber, S., Gianolini, M. E., Pala, M., LiconaLimon, P., et al. (2013). Coexpression of CD49b and LAG-3 identifies human and mouse $\mathrm{T}$ regulatory type 1 cells. Nat. Med. doi:10.1038/nm.3179

Gambineri, E., Torgerson, T. R., and Ochs, H. D. (2003). Immune dysregulation, polyendocrinopathy, enteropathy, and X-linked inheritance (IPEX), a syndrome of systemic autoimmunity caused by mutations of FOXP3, a critical regulator of T-cell homeostasis. Curr. Opin. Rheumatol. 15, 430-435. doi:10.1097/00002281200307000-00010

Garcia-Hernandez, M. L., HernandezPando, R., Gariglio, P., and Berumen, J. (2002). Interleukin-10 promotes B16-melanoma growth by inhibition of macrophage functions and induction of tumour and vascular cell proliferation. Immunology 105, 231-243. doi:10.1046/j.13652567.2002.01363.x

Gazzinelli, R. T., Wysocka, M., Hayashi, S., Denkers, E. Y., Hieny, S., Caspar, P., et al. (1994). Parasiteinduced IL-12 stimulates early IFNgamma synthesis and resistance during acute infection with Toxoplasma gondii. J. Immunol. 153, 2533-2543.

Gazzinelli, R. T., Wysocka, M., Hieny, S., Scharton-Kersten, T., Cheever, A., Kühn, R., et al. (1996). In the absence of endogenous IL-10, mice acutely infected with Toxoplasma gondii succumb to a lethal immune response dependent on $\mathrm{CD} 4+\mathrm{T}$ cells and accompanied by overproduction of IL-12, IFN-gamma and TNF-alpha. J. Immunol. 157, 798-805.

Gerard, C. M., Bruyns, C., Delvaux, A., Baudson, N., Dargent, J. L., Goldman, M., et al. (1996). Loss of tumorigenicity and increased immunogenicity induced by interleukin-10 gene transfer in B16 melanoma cells. Hum. Gene Ther. 7, 23-31. doi:10.1089/hum.1996.7.1-23

Gerosa, F., Nisii, C., Righetti, S., Micciolo, R., Marchesini, M., Cazzadori, A., et al. (1999). $\mathrm{CD} 4(+) \mathrm{T}$ cell clones producing both interferon-gamma and interleukin-10 predominate in bronchoalveolar lavages of active pulmonary tuberculosis patients. Clin. Immunol. 92, 224-234. doi:10.1006/clim.1999.4752

Gibson, A. W., Edberg, J. C., Wu, J., Westendorp, R. G. J., Huizinga, T. W. J., and Kimberly, R. P. (2001). Novel Single nucleotide polymorphisms in the distal IL-10 promoter affect IL10 production and enhance the risk of systemic lupus erythematosus. $J$. Immunol. 166, 3915-3922.

Giovarelli, M., Musiani, P., Modesti, A., Dellabona, P., Casorati, G., Allione, A., et al. (1995). Local release of IL-10 by transfected mouse mammary adenocarcinoma cells does not suppress but enhances antitumor reaction and elicits a strong cytotoxic lymphocyte and antibodydependent immune memory. $J$. Immunol. 155, 3112-3123.

Gonzalez-Aragoneses, F., MorenoMata, N., Cebollero-Presmanes, M., Garcia-Yuste, M., CanizaresCarretero, M. A., Molins-LopezRodo, L., et al. (2007). Prognostic significance of synaptophysin in stage I of squamous carcinoma and adenocarcinoma of the lung. Cancer 110, 1776-1781. doi:10.1002/cncr.22985

Gottschalk, R. A., Corse, E., and Allison, J. P. (2012). Expression of helios in peripherally induced Foxp3+ regulatory $\mathrm{T}$ cells. J. Immunol. 188, 976-980. doi:10.4049/jimmunol.1102964

Gregori, S., Tomasoni, D., Pacciani, V., Scirpoli, M., Battaglia, M., Magnani, C. F., et al. (2010). Differentiation of type $1 \mathrm{~T}$ regulatory cells $(\operatorname{Tr} 1)$ by tolerogenic DC10 requires the IL-10-dependent ILT4/HLA-G pathway. Blood 116,
935-944. doi:10.1182/blood-200907-234872

Groux, H., Bigler, M., de Vries, J. E., and Roncarolo, M. G. (1998). Inhibitory and stimulatory effects of IL-10 on human CD8+ T cells. J. Immunol. 160, 3188-3193.

Groux, H., Cottrez, F., Rouleau, M., Mauze, S., Antonenko, S., Hurst, S., et al. (1999). A transgenic model to analyze the immunoregulatory role of IL-10 secreted by antigenpresenting cells. J. Immunol. 162, 1723-1729.

Groux, H., O'Garra, A., Bigler, M., Rouleau, M., Antonenko, S., de Vries, J. E., et al. (1997). A CD4+ T-cell subset inhibits antigenspecific T-cell responses and prevents colitis. Nature 389, 737-742. doi:10.1038/39614

Grünig, G., Corry, D. B., Leach, M. W., Seymour, B. W. P., Kurup, V. P., and Rennick, D. M. (1997). Interleukin10 is a natural suppressor of cytokine production and inflammation in a murine model of allergic bronchopulmonary Aspergillosis. J. Exp. Med. 185, 1089-1100. doi:10.1084/jem.185.6.1089

Hajeer, A. H., Lazarus, M., Turner, D., Mageed, R. A., Vencovsky, J., Sinnott, P., et al. (1998). IL-10 gene promoter polymorphisms in rheumatoid arthritis. Scand. J. Rheumatol. 27, 142-145. doi:10.1080/030097498441029

Halak, B. K., Maguire, H. C. Jr., and Lattime, E. C. (1999). Tumorinduced interleukin-10 inhibits type 1 immune responses directed at a tumor antigen as well as a nontumor antigen present at the tumor site. Cancer Res. 59, 911-917.

Hashimoto, T., Akiyama, K., Kobayashi, N., and Mori, A. (2005). Comparison of IL-17 production by helper $\mathrm{T}$ cells among atopic and nonatopic asthmatics and control subjects. Int Arch. Allergy Immunol. 137(Suppl. 1), 51-54. doi:10.1159/000 085432

Hata, H., Sakaguchi, N., Yoshitomi, H., Iwakura, Y., Sekikawa, K., Azuma, Y., et al. (2004). Distinct contribution of IL-6, TNF-alpha, IL-1, and IL-10 to T cell-mediated spontaneous autoimmune arthritis in mice. J. Clin. Invest. 114, 582-588. doi:10.1172/JCI21795

Hawrylowicz, C., Richards, D., Loke, T. K., Corrigan, C., and Lee, T. A. (2002). defect in corticosteroidinduced IL-10 production in $\mathrm{T}$ lymphocytes from corticosteroidresistant asthmatic patients. $J$. Allergy Clin. Immunol. 109, 369-370. doi:10.1067/mai.2002.121455
Himmel, M. E., MacDonald, K. G., Garcia, R. V., Steiner, T. S., and Levings, M. K. (2013). Helios+ and helios- cells coexist within the natural FOXP3+ $\mathrm{T}$ regulatory cell subset in humans. J. Immunol. 190, 2001-2008. doi:10.4049/jimmunol.1201379

Hjorth, M., Axelsson, S., Ryden, A., Faresjo, M., Ludvigsson, J., and Casas, R. (2011). GAD-alum treatment induces GAD65-specific CD4+CD25highFOXP3+ cells in type 1 diabetic patients. Clin. Immunol. 138, 117-126. doi:10.1016/j.clim.2010.10.004

Hori, S., Nomura, T., and Sakaguchi, S. (2003). Control of regulatory $\mathrm{T}$ cell development by the transcription factor Foxp3. Science 299, 1057-1061. doi:10.1126/science. 1079490

Huber, S., Gagliani, N., Esplugues, E., O'Connor, W. Jr., Huber, F. J., Chaudhry, A., et al. (2011). Th17 cells express interleukin-10 receptor and are controlled by Foxp3(-) and Foxp3+ regulatory CD4+ $\mathrm{T}$ cells in an interleukin-10-dependent manner. Immunity 34, 554-565. doi:10.1016/j.immuni.2011. 01.020

Hunter, C. A., Ellis-Neyes, L. A., Slifer, T., Kanaly, S., Grunig, G., Fort, M., et al. (1997). IL-10 is required to prevent immune hyperactivity during infection with Trypanosoma cruzi. J. Immunol. 158, 3311-3316.

Ilarregui, J. M., Croci, D. O., Bianco, G. A., Toscano, M. A., Salatino, M., Vermeulen, M. E., et al. (2009). Tolerogenic signals delivered by dendritic cells to $\mathrm{T}$ cells through a galectin-1-driven immunoregulatory circuit involving interleukin 27 and interleukin 10. Nat. Immunol. 10, 981-991. doi:10.1038/ni.1772

Im, S. H., Hueber, A., Monticelli, S., Kang, K. H., and Rao, A. (2004). Chromatin-level regulation of the IL10 gene in T cells. J. Biol. Chem. 279, 46818-46825. doi:10.1074/jbc.M401722200

Ivanov, I. I., McKenzie, B. S., Zhou, L., Tadokoro, C. E., Lepelley, A., Lafaille, J. J., et al. (2006). The orphan nuclear receptor $\mathrm{ROR}^{3} \mathrm{t}$ directs the differentiation program of proinflammatory IL-17+ T helper cells. Cell 126, 1121-1133. doi:10.1016/j.cell.2006.07.035

Jacobs, Z., and Ciaccio, C. E. (2010). Periodic fever syndromes. Curr. Allergy Asthma Rep. 10, 398-404. doi:10.1007/s11882-010-0141-z

Johansson, L., Rytkönen, A., Wan, H., Bergman, P., Plant, L., Agerberth, B., et al. (2005). Human-like immune 
responses in CD46 transgenic mice. J. Immunol. 175, 433-440.

John, M., Lim, S. A. M., Seybold, J., Jose, P., Robichaud, A., O’Connor, B., et al. (1998). Inhaled corticosteroids increase interleukin-10 but reduce macrophage inflammatory protein$1 \alpha$, granulocyte-macrophage colony-stimulating factor, and interferon- $\gamma$ release from alveolar macrophages in asthma. Am. J. Respir. Crit. Care Med. 157, 256-262. doi:10.1164/ajrccm.157.1.9703079

Josefowicz, S. Z., Niec, R. E., Kim, H. Y., Treuting, P., Chinen, T., Zheng, Y., et al. (2012). Extrathymically generated regulatory $\mathrm{T}$ cells control mucosal TH2 inflammation. Nature 482, 395-399. doi:10.1038/nature10772

Jutel, M., Akdis, M., Budak, F., Aebischer-Casaulta, C., Wrzyszcz, M., Blaser, K., et al. (2003). IL-10 and TGF- $\beta$ cooperate in the regulatory $\mathrm{T}$ cell response to mucosal allergens in normal immunity and specific immunotherapy. Eur. J. Immunol. 33, 1205-1214. doi:10.1002/eji.200322919

Kappos, L., Comi, G., Panitch, H., Oger, J., Antel, J., Conlon, P., et al. (2000). Induction of a non-encephalitogenic type $2 \mathrm{~T}$ helper-cell autoimmune response in multiple sclerosis after administration of an altered peptide ligand in a placebo-controlled, randomized phase II trial. The altered peptide ligand in relapsing MS study group. Nat. Med. 6, 1176-1182. doi:10.1038/80525

Karagiannidis, C., Akdis, M., Holopainen, P., Woolley, N. J., Hense, G., Rückert, B., et al. (2004). Glucocorticoids upregulate FOXP3 expression and regulatory $\mathrm{T}$ cells in asthma. J. Allergy Clin. Immunol. 114, 1425-1433. doi:10.1016/j.jaci.2004.07.014

Kemp, K., Kemp, M., Kharazmi, A., Ismail, A., Kurtzhals, J. A., Hviid, L., et al. (1999). Leishmaniaspecific T cells expressing interferongamma (IFN-gamma) and IL10 upon activation are expanded in individuals cured of visceral leishmaniasis. Clin. Exp. Immunol. 116, 500-504. doi:10.1046/j.13652249.1999.00918.x

Kemper, C., Chan, A. C., Green, J. M., Brett, K. A., Murphy, K. M., and Atkinson, J. P. (2003). Activation of human CD4+ cells with CD3 and CD46 induces a T-regulatory cell 1 phenotype. Nature 421, 388-392. doi:10.1038/nature01315

Kim, J., Modlin, R. L., Moy, R. L., Dubinett, S. M., McHugh, T., Nickoloff, B. J., et al. (1995). IL-10 production in cutaneous basal and squamous cell carcinomas. A mechanism for evading the local $\mathrm{T}$ cell immune response. J. Immunol. 155, 2240-2247.

Kim, J. I., Ho, I. C., Grusby, M. J., and Glimcher, L. H. (1999). The transcription factor c-Maf controls the production of interleukin- 4 but not other Th2 cytokines. Immunity 10, 745-751. doi:10.1016/S10747613(00)80073-4

Korenaga, M., Hitoshi, Y., Yamaguchi, N., Sato, Y., Takatsu, K., and Tada, I. (1991). The role of interleukin-5 in protective immunity to Strongyloides venezuelensis infection in mice. Immunology 72, 502-507.

Kornete, M., Sgouroudis, E., and Piccirillo, C. A. (2012). ICOSdependent homeostasis and function of Foxp3 + regulatory $\mathrm{T}$ cells in islets of nonobese diabetic mice. J. Immunol. 188, 1064-1074. doi:10.4049/jimmunol.1101303

Kubo, M., and Motomura, Y. (2012). Transcriptional regulation of the anti-inflammatory cytokine IL-10 in acquired immune cells. Front. Immunol. 3:275 doi:10.3389/fimmu.2012.00275

Kühn, R., Löhler, J., Rennick, D., Rajewsky, K., and Müller, W. (1993). Interleukin-10-deficient mice develop chronic enterocolitis. Cell 75, 263-274. doi:10.1016/0092-8674(93)80068-P

Lauw, F. N., Pajkrt, D., Hack, C. E., Kurimoto, M., van Deventer, S. J., and van der Poll, T. (2000). Proinflammatory effects of IL-10 during human endotoxemia. J. Immunol. 165, 2783-2789.

Lavelle, E. C., Jarnicki, A., McNeela, E., Armstrong, M. E., Higgins, S. C., Leavy, O., et al. (2004). Effects of cholera toxin on innate and adaptive immunity and its application as an immunomodulatory agent. J. Leukoc. Biol. 75, 756-763. doi:10.1189/jlb.1103534

Lavelle, E. C., McNeela, E., Armstrong, M. E., Leavy, O., Higgins, S. C., and Mills, K. H. G. (2003). Cholera toxin promotes the induction of regulatory $\mathrm{T}$ cells specific for Bystander antigens by modulating dendritic cell activation. J. Immunol. 171, 2384-2392.

Lech-Maranda, E., Baseggio, L., Bienvenu, J., Charlot, C., Berger, F., Rigal, D., et al. (2004). Interleukin10 gene promoter polymorphisms influence the clinical outcome of diffuse large B-cell lymphoma. Blood 103, 3529-3534. doi:10.1182/blood2003-06-1850

LeMaoult, J., Krawice-Radanne, I., Dausset, J., and Carosella, E.
D. (2004). HLA-G1-expressing antigen-presenting cells induce immunosuppressive CD4+ $\mathrm{T}$ cells. Proc. Natl. Acad. Sci. U.S.A. 101, 7064-7069. doi:10.1073/pnas.0401922101

Leon, L. R., Kozak, W., and Kluger, M. J. (1998). Role of IL-10 in inflammation. Studies using cytokine knockout mice. Ann. N. Y. Acad. Sci. 856, 69-75. doi:10.1111/j.17496632.1998.tb08314.x

Lim, S., Crawley, E., Woo, P., and Barnes, P. J. (1998). Haplotype associated with low interleukin-10 production in patients with severe asthma. Lancet 352, 113. doi:10.1016/S01406736(98)85018-6

Linden, A., Hoshino, H., and Laan, M. (2000). Airway neutrophils and interleukin-17. Eur. Respir. J. 15, 973-977. doi:10.1034/j.13993003.2000.15e28.x

Linke, A., Kuhn, R., Muller, W., Honarvar, N., Li, C., and Langhorne, J. (1996). Plasmodium chabaudi: differential susceptibility of genetargeted mice deficient in IL10 to an erythrocytic-stage infection. Exp. Parasitol. 84, 253-263. doi:10.1006/expr.1996.0111

Lucas, S., Ghilardi, N., Li, J., and de Sauvage, F. J. (2003). IL-27 regulates IL-12 responsiveness of naive $\mathrm{CD} 4+\mathrm{T}$ cells through Stat1-dependent and -independent mechanisms. Proc. Natl. Acad. Sci. U.S.A. 100, 15047-15052. doi:10.1073/pnas.2536517100

Ludvigsson, J., Krisky, D., Casas, R. Battelino, T., Castaño, L., Greening, J., et al. (2012). GAD65 antigen therapy in recently diagnosed type 1 diabetes mellitus. N. Engl. J. Med. 366, 433-442. doi:10.1056/NEJMoa1107096

Male, V., Nisoli, I., Gascoyne, D. M., and Brady, H. J. M. (2012). E4BP4: an unexpected player in the immune response. Trends Immunol. 33, 98-102. doi:10.1016/j.it.2011.10.002

Maloy, K. J., and Powrie, F. (2001) Regulatory $\mathrm{T}$ cells in the control of immune pathology. Nat. Immunol. 2, 816-822. doi:10.1038/ni 0901-816

Manavalan, J. S., Rossi, P. C., Vlad, G., Piazza, F., Yarilina, A., Cortesini, R., et al. (2003). High expression of ILT3 and ILT4 is a general feature of tolerogenic dendritic cells. Transpl. Immunol. 11, 245-258. doi:10. 1016/S0966-3274(03)00058-3

Mathisen, P. M., Yu, M., Johnson, J. M., Drazba, J. A., and Tuohy, V. K. (1997). Treatment of experimental autoimmune encephalomyelitis with genetically modified memory
T cells. J. Exp. Med. 186, 159-164. doi:10.1084/jem.186.1.159

Matusevicius, D., Kivisakk, P., He, B., Kostulas, N., Ozenci, V., Fredrikson, S., et al. (1999). Interleukin-17 mRNA expression in blood and CSF mononuclear cells is augmented in multiple sclerosis. Mult. Scler. 5, 101-104. doi:10.1191/135245899678847275

Mauri, C., and Bosma, A. (2012). Immune regulatory function of B cells. Annu. Rev. Immunol. 30, 221-241. doi:10.1146/annurevimmunol-020711-074934

Maynard, C. L., Harrington, L. E., Janowski, K. M., Oliver, J. R., Zindl, C. L., Rudensky, A. Y., et al. (2007). Regulatory $\mathrm{T}$ cells expressing interleukin 10 develop from Foxp3+ and Foxp3-precursor cells in the absence of interleukin 10. Nat. Immunol. 8, 931-941. doi:10.1038/ni1504

Maynard, C. L., and Weaver, C. T. (2008). Diversity in the contribution of interleukin-10 to T-cell-mediated immune regulation. Immunol. Rev. 226, 219-233. doi:10.1111/j.1600065X.2008.00711.x

McGeachy, M. J., Bak-Jensen, K. S., Chen, Y., Tato, C. M., Blumenschein, W., McClanahan, T., et al. (2007). TGF-beta and IL-6 drive the production of IL-17 and IL-10 by T cells and restrain $\mathrm{T}(\mathrm{H})-17$ cellmediated pathology. Nat. Immunol. 8, 1390-1397. doi:10.1038/ ni1539

McGeachy, M. J., Chen, Y., Tato, C. M., Laurence, A., Joyce-Shaikh, B., Blumenschein, W. M., et al. (2009). The interleukin 23 receptor is essential for the terminal differentiation of interleukin 17-producing effector $\mathrm{T}$ helper cells in vivo. Nat. Immunol. 10, 314-324. doi:10.1038/ni.1698

Meiler, F., Zumkehr, J., Klunker, S. Rückert, B., Akdis, C. A., and Akdis, M. (2008). In vivo switch to IL-10-secreting $\mathrm{T}$ regulatory cells in high dose allergen exposure. J. Exp. Med. 205, 2887-2898. doi:10.1084/jem.20080193

Metzler, B., and Wraith, D. C. (1993). Inhibition of experimental autoimmune encephalomyelitis by inhalation but not oral administration of the encephalitogenic peptide: influence of MHC binding affinity. Int. Immunol. 5, 1159-1165. doi:10.1093/intimm/5.9.1159

Micallef, M. J., Tanimoto, T., Torigoe, K., Nishida, Y., Kohno, K., Ikegami, H., et al. (1999). Simultaneous exposure to interleukin-18 and interleukin-10 in vitro synergistically augments murine spleen natural killer cell activity. Cancer 
Immunol. Immunother. 48, 109-117. doi:10.1007/s002620050554

Miller, S. D., Turley, D. M., and Podojil, J. R. (2007). Antigen-specific tolerance strategies for the prevention and treatment of autoimmune disease. Nat. Rev. Immunol. 7, 665-677. doi:10.1038/nri2153

Moore, K. W., de Waal Malefyt, R., Coffman, R. L., and O'Garra, A. (2001). Interleukin-10 and the interleukin-10 receptor. Annu. Rev. Immunol. 19, 683-765. doi:10. 1146/annurev.immunol.19.1.683

Morinobu, A., Gadina, M., Strober, W., Visconti, R., Fornace, A., Montagna, C., et al. (2002). STAT4 serine phosphorylation is critical for IL12 -induced IFN- $\gamma$ production but not for cell proliferation. Proc. Natl. Acad. Sci. U.S.A. 99, 12281-12286. doi:10.1073/pnas.182618999

Motomura, Y., Kitamura, H., Hijikata, A., Matsunaga, Y., Matsumoto, K., Inoue, H., et al. (2011). The transcription factor E4BP4 regulates the production of IL-10 and IL-13 in CD4+ T cells. Nat. Immunol. 12, 450-459. doi:10.1038/ni.2020

Muller, S., Monneaux, F., Schall, N., Rashkov, R. K., Oparanov, B. A., Wiesel, P., et al. (2008). Spliceosomal peptide P140 for immunotherapy of systemic lupus erythematosus: results of an early phase II clinical trial. Arthritis Rheum. 58, 3873-3883. doi:10.1002/art. 24027

Nagelkerken, L., Blauw, B., and Tielemans, M. (1997). IL-4 abrogates the inhibitory effect of IL-10 on the development of experimental allergic encephalomyelitis in SJL mice. Int. Immunol. 9, 1243-1251.

Nemunaitis, J., Fong, T., Shabe, P., Martineau, D., and Ando, D. (2001). Comparison of serum interleukin-10 (IL-10) levels between normal volunteers and patients with advanced melanoma. Cancer Invest. 19, 239-247. doi:10.1081/CNV-100102550

Northrop, J. K., Thomas, R. M., Wells, A. D., and Shen, H. (2006). Epigenetic remodeling of the IL-2 and IFN-gamma loci in memory CD8 T cells is influenced by CD4 T cells. J. Immunol. 177, 1062-1069.

Oakley, O. R., Garvy, B. A., Humphreys, S., Qureshi, M. H., and Pomeroy, C. (2008). Increased weight loss with reduced viral replication in interleukin10 knock-out mice infected with murine cytomegalovirus. Clin. Exp. Immunol. 151, 155-164. doi:10.1111/j.13652249.2007.03533.x
O'Garra, A., Barrat, F. J., Castro, A. G., Vicari, A., and Hawrylowicz, C. (2008). Strategies for use of IL-10 or its antagonists in human disease. Immunol. Rev. 223, 114-131. doi:10.1111/j.1600065X.2008.00635.x

O'Garra, A., and Vieira, P. (2004). Regulatory $\mathrm{T}$ cells and mechanisms of immune system control. Nat. Med. 10, 801-805. doi:10.1038/nm0804801

O'Garra, A., and Vieira, P. (2007). $\mathrm{T}(\mathrm{H}) 1$ cells control themselves by producing interleukin-10. Nat. Rev. Immunol. 7, 425-428. doi:10.1038/nri2097

Ouyang, W., Löhning, M., Gao, Z., Assenmacher, M., Ranganath, S., Radbruch, A., et al. (2000). Stat6independent GATA-3 autoactivation directs IL-4-independent Th2 development and commitment. Immunity 12, 27-37. doi:10.1016/S10747613(00)80156-9

Pacholczyk, R., Ignatowicz, H., Kraj, P., and Ignatowicz, L. (2006). Origin and $\mathrm{T}$ cell receptor diversity of Foxp3+CD4+CD25+ $\mathrm{T}$ cells. Immunity 25, 249-259. doi:10.1016/j.immuni.2006.05.016

Pot, C., Jin, H., Awasthi, A., Liu, S. M., Lai, C.-Y., Madan, R., et al. (2009). Cutting edge: IL-27 induces the transcription factor $\mathrm{c}$ Maf, cytokine IL-21, and the costimulatory receptor ICOS that coordinately act together to promote differentiation of IL-10-producing Tr1 cells. J. Immunol. 183, 797-801. doi:10.4049/jimmunol.0901233

Prakken, B. J., Samodal, R., Le, T. D., Giannoni, F., Yung, G. P., Scavulli, J., et al. (2004). Epitope-specific immunotherapy induces immune deviation of proinflammatory $\mathrm{T}$ cells in rheumatoid arthritis. Proc. Natl. Acad. Sci. U.S.A. 101, 4228-4233. doi:10.1073/pnas.0400061101

Redford, P. S., Murray, P. J., and O'Garra, A. (2011). The role of IL-10 in immune regulation during M. tuberculosis infection. Mucosal Immunol. 4, 261-270. doi:10.1038/mi.2011.7

Reich, K., Garbe, C., Blaschke, V., Maurer, C., Middel, P., Westphal, G., et al. (2001). Response of psoriasis to interleukin-10 is associated with suppression of cutaneous type 1 inflammation, downregulation of the epidermal interleukin8//CXCR2 pathway and normalization of keratinocyte maturation. J. Invest. Dermatol. 116, 319-329.

Richards, D. F., Fernandez, M., Caulfield, J., and Hawrylowicz, C. M. (2000). Glucocorticoids drive human CD8 $+\mathrm{T}$ cell differentiation towards a phenotype with high IL-10 and reduced IL-4, IL-5 and IL-13 production. Eur. J. Immunol. 30, 2344-2354. doi:10.1002/15214141(2000)30:8<2344::AIDIMMU2344>3.0.CO;2-7

Rizzo, L. V., Xu, H., Chan, C. C., Wiggert, B., and Caspi, R. R. (1998). IL-10 has a protective role in experimental autoimmune uveoretinitis. Int. Immunol. 10, 807-814. doi:10.1093/intimm/10.6.807

Robinson, D. S., Hamid, Q., Ying, S., Tsicopoulos, A., Barkans, J., Bentley, A. M., et al. (1992). Predominant TH2like bronchoalveolar T-lymphocyte population in atopic asthma. N. Engl. J. Med. 326, 298-304. doi:10.1056/NEJM199201303260504

Rogge, L., Barberis-Maino, L., Biffi, M., Passini, N., Presky, D. H., Gubler, U., et al. (1997). Selective expression of an interleukin-12 receptor component by human $\mathrm{T}$ helper 1 cells. J. Exp. Med. 185, 825-832. doi:10.1084/jem.185.5.825

Romagnani, S. (1994). Lymphokine production by human $\mathrm{T}$ cells in disease states. Annu. Rev. Immunol. 12, 227-257. doi:10. 1146/annurev.iy.12.040194.001303

Romagnani, S. (1996). TH1 and TH2 in human diseases. Clin. Immunol. Immunopathol. 80, 225-235. doi:10.1006/clin.1996.0118

Roncarolo, M. G., Gregori, S., Battaglia, M., Bacchetta, R., Fleischhauer, K., and Levings, M. K. (2006). Interleukin-10-secreting type 1 regulatory $\mathrm{T}$ cells in rodents and humans. Immunol. Rev. 212, 28-50. doi:10.1111/j.01052896.2006.00420.x

Rubtsov, Y. P., Rasmussen, J. P., Chi, E. Y., Fontenot, J., Castelli, L., Ye, X., et al. (2008). Regulatory $\mathrm{T}$ cell-derived interleukin-10 limits inflammation at environmental interfaces. Immunity 28, 546-558. doi:10.1016/j.immuni.2008.02.017

Sabatos-Peyton, C. A., Verhagen, J., and Wraith, D. C. (2010). Antigen-specific immunotherapy of autoimmune and allergic diseases. Curr. Opin. Immunol. 22, 609-615. doi:10.1016/j.coi.2010.08.006

Samstein, R. M., Josefowicz, S. Z., Arvey, A., Treuting, P. M., and Rudensky, A. Y. (2012). Extrathymic generation of regulatory $\mathrm{T}$ cells in placental mammals mitigates maternalfetal conflict. Cell 150, 29-38. doi:10.1016/j.cell.2012.05.031

Saraiva, M., Christensen, J. R., Veldhoen, M., Murphy, T. L., Murphy, K. M., and O'Garra, A. (2009). Interleukin10 production by Th1 cells requires interleukin-12-induced STAT4 transcription factor and ERK MAP kinase activation by high antigen dose. Immunity 31, 209-219. doi:10.1016/j.immuni.2009.05.012

Saraiva, M., and O'Garra, A. (2010). The regulation of IL-10 production by immune cells. Nat. Rev. Immunol. 10, 170-181. doi:10.1038/nri2711

Schall, N., Page, N., Macri, C., Chaloin, O., Briand, J.-P., and Muller, S. (2012). Peptide-based approaches to treat lupus and other autoimmune diseases. J. Autoimmun. 39, 143-153. doi:10.1016/j.jaut.2012.05.016

Schopf, L. R., Hoffmann, K. F., Cheever, A. W., Urban, J. F., and Wynn, T. A. (2002). IL-10 is critical for host resistance and survival during gastrointestinal helminth infection. J. Immunol. 168, 2383-2392.

Sellon, R. K., Tonkonogy, S., Schultz, M., Dieleman, L. A., Grenther, W., Balish E., et al. (1998). Resident enteric bacteria are necessary for development of spontaneous colitis and immune system activation in interleukin-10deficient mice. Infect. Immun. 66, 5224-5231.

Shoda, L. K., Young, D. L., Ramanujan, S., Whiting, C. C., Atkinson, M. A., Bluestone, J. A., et al. (2005). A comprehensive review of interventions in the NOD mouse and implications for translation. Immunity 23, 115-126. doi:10.1016/j.immuni.2005.08.002

Shoemaker, J., Saraiva, M., and O'Garra, A. (2006). GATA-3 directly remodels the IL-10 locus independently of IL4 in CD4+ T cells. J. Immunol. 176, 3470-3479.

Sieling, P. A., Abrams, J. S., Yamamura, M., Salgame, P., Bloom, B. R., Rea, T. H., et al. (1993). Immunosuppressive roles for IL-10 and IL-4 in human infection. In vitro modulation of $\mathrm{T}$ cell responses in leprosy. $J$. Immunol. 150, 5501-5510.

Silva, J. S., Morrissey, P. J., Grabstein, K. H., Mohler, K. M., Anderson, D., and Reed, S. G. (1992). Interleukin 10 and interferon gamma regulation of experimental Trypanosoma cruzi infection. J. Exp. Med. 175, 169-174. doi:10.1084/jem.175.1.169

Slavin, A. J., Maron, R., and Weiner, H. L. (2001). Mucosal administration of IL-10 enhances oral tolerance in autoimmune encephalomyelitis and diabetes. Int. Immunol. 13, 825-833. doi:10.1093/intimm/13.6.825

Steinman, L. A. (2007). brief history of $\mathrm{TH} 17$, the first major revision in the TH1/TH2 hypothesis of T cellmediated tissue damage. Nat. Med. 13, 139-145. doi:10.1038/nm0307$385 \mathrm{a}$ 
Stumhofer, J. S., Silver, J. S., Laurence, A., Porrett, P. M., Harris, T. H., Turka, L. A., et al. (2007). Interleukins 27 and 6 induce STAT3-mediated $\mathrm{T}$ cell production of interleukin 10. Nat. Immunol. 8, 1363-1371. doi:10.1038/ni1537

Sun, J., Madan, R., Karp, C. L., and Braciale, T. J. (2009). Effector T cells control lung inflammation during acute influenza virus infection by producing IL-10. Nat. Med. 15, 277-284. doi:10.1038/nm.1929

Suri-Payer, E., and Cantor, H. (2001). Differential cytokine requirements for regulation of autoimmune gastritis and colitis by $\mathrm{CD} 4(+) \mathrm{CD} 25(+) \mathrm{T}$ cells. J. Autoimmun. 16, 115-123. doi:10.1006/jaut.2000.0473

Taylor, A., Akdis, M., Joss, A., Akkoç, T., Wenig, R., Colonna, M., et al. (2007). IL-10 inhibits CD28 and ICOS costimulations of $\mathrm{T}$ cells via src homology 2 domain-containing protein tyrosine phosphatase 1. J. Allergy Clin. Immunol. 120, 76-83. doi:10.1016/j.jaci.2007.04.004

Taylor, A., Verhagen, J., Akkoc, T., Wenig, R., Flory, E., Blaser, K., et al. (2009). IL-10 suppresses CD2-mediated $\mathrm{T}$ cell activation via SHP-1. Mol. Immunol. 46, 622-629. doi:10.1016/j.molimm.2008. 07.031

Thornton, A. M., Korty, P. E., Tran, D. Q., Wohlfert, E. A., Murray, P. E., Belkaid, Y., et al. (2010). Expression of helios, an Ikaros transcription factor family member, differentiates thymic-derived from peripherally induced Foxp3 $+\mathrm{T}$ regulatory cells. J. Immunol. 184, 3433-3441. doi:10.4049/jimmunol.09 04028

Thrower, S. L., James, L., Hall, W., Green, K. M., Arif, S., Allen, J. S., et al. (2009). Proinsulin peptide immunotherapy in type 1 diabetes: report of a first-in-man Phase I safety study. Clin. Exp. Immunol. 155, 156-165. doi:10.1111/j.13652249.2008.03814.x

Tian, J., Atkinson, M. A., Clare-Salzler, M., Herschenfeld, A., Forsthuber, T., Lehmann, P. V., et al. (1996). Nasal administration of glutamate decarboxylase (GAD65) peptides induces Th2 responses and prevents murine insulin-dependent diabetes.
J. Exp. Med. 183, 1561-1567. doi:10.1084/jem.183.4.1561

Tilg, H., van Montfrans, C., van den Ende, A., Kaser, A., van Deventer, S. J., Schreiber, S., et al. (2002). Treatment of Crohn's disease with recombinant human interleukin 10 induces the proinflammatory cytokine interferon gamma. Gut 50, 191-195. doi:10.1136/gut.50.2.191

Trinchieri, G. (2007). Interleukin10 production by effector $\mathrm{T}$ cells: Th1 cells show self control. J. Exp. Med. 204, 239-243. doi:10.1084/jem.20070104

Uhlig, H. H., Coombes, J., Mottet, C., Izcue, A., Thompson, C., Fanger, A., et al. (2006). Characterization of Foxp3+CD4+CD25+ and IL-10secreting CD4+CD25+ T cells during cure of colitis. J. Immunol. 177, 5852-5860.

Umetsu, D. T., and DeKruyff, R. H. (1997). TH1 and TH2 CD4+ cells in human allergic diseases. J. Allergy Clin. Immunol. 100, 1-6. doi:10. 1016/S0091-6749(97)70186-6

Umetsu, D. T., and DeKruyff, R. H. (1999). Interleukin-10: The missing link in asthma regulation? Am. J. Respir. Cell Mol. Biol. 21, 562-563. doi:10.1165/ajrcmb.21.5.f171

Urban, J. F. Jr., Katona, I. M., Paul, W. E., and Finkelman, F. D. (1991). Interleukin 4 is important in protective immunity to a gastrointestinal nematode infection in mice. Proc. Natl. Acad. Sci. U.S.A. 88, 5513-5517. doi:10.1073/pnas.88.13.5513

Van Boxel-Dezaire, A. H. H., Hoff, S. C. J., Van Oosten, B. W., Verweij, C. L., Dräger, A. M., Adèr, H. J., et al. (1999). Decreased interleukin-10 and increased interleukin-12p40 mRNA are associated with disease activity and characterize different disease stages in multiple sclerosis. Ann. Neurol. 45, 695-703. doi:10.1002/15318249(199906)45:6<695::AIDANA3 > 3.0.CO;2-R

Verhagen, J., and Wraith, D. C. (2010). Comment on "expression of helios, an Ikaros transcription factor family member, differentiates thymic-derived from peripherally induced Foxp3 $+\mathrm{T}$ regulatory cells". J. Immunol. 185, 7129. doi:10.4049/jimmunol.1090105
Vissers, J. L., van Esch, B. C., Hofman, G. A., Kapsenberg, M. L. Weller, F. R., and van Oosterhout, A. J. (2004). Allergen immunotherapy induces a suppressive memory response mediated by IL-10 in a mouse asthma model. J. Allergy Clin. Immunol. 113, 1204-1210. doi:10.1016/j.jaci.2004.02.041

Warren, K. G., Catz, I., Ferenczi, L. Z. and Krantz, M. J. (2006). Intravenous synthetic peptide MBP8298 delayed disease progression in an HLA Class II-defined cohort of patients with progressive multiple sclerosis: results of a 24-month double-blind placebo-controlled clinical trial and 5 years of followup treatment. Eur. J. Neurol. 13, 887-895. doi:10.1111/j.14681331.2006.01533.x

Weiss, J. M., Bilate, A. M., Gobert, M., Ding, Y., Curotto de Lafaille, M. A., Parkhurst, C. N., et al. (2012). Neuropilin 1 is expressed on thymus-derived natural regulatory $\mathrm{T}$ cells, but not mucosagenerated induced Foxp3+ $\mathrm{T}$ reg cells. J. Exp. Med. 209, 1723-1742. doi:10.1084/jem.20120914

Wong, C. K., Ho, C. Y., Li, E. K., and Lam, C. W. (2000). Elevation of proinflammatory cytokine (IL-18, IL-17, IL-12) and Th2 cytokine (IL-4) concentrations in patients with systemic lupus erythematosus. Lupus 9, 589-593. doi:10.1191/096120300678 828703

$\mathrm{Xu}$, J., Yang, Y., Qiu, G., Lal, G. Wu, Z., Levy, D. E., et al. (2009). c-Maf regulates IL-10 expression during Th17 polarization. J. Immunol. 182, 6226-6236. doi:10.4049/jimmunol.0900123

Xystrakis, E., Kusumakar, S., Boswell, S., Peek, E., and Urry, Z. (2006). Reversing the defective induction of IL-10-secreting regulatory $\mathrm{T}$ cells in glucocorticoid-resistant asthma patients. J. Clin. Invest. 116, 146-155. doi:10.1172/jci21759

Yadav, M., Louvet, C., Davini, D., Gardner, J. M., Martinez-Llordella, M. Bailey-Bucktrout, S., et al. (2012). Neuropilin-1 distinguishes natural and inducible regulatory $\mathrm{T}$ cells among regulatory $\mathrm{T}$ cell subsets in vivo. J. Exp. Med. 209, 1713-1722. doi:10.1084/jem.20120822
Yang, A. S., and Lattime, E. C. (2003). Tumor-induced interleukin 10 suppresses the ability of splenic dendritic cells to stimulate CD4 and CD8 T-cell responses. Cancer Res. 63, 2150-2157.

Zaffran, Y., Destaing, O., Roux, A., Ory, S., Nheu, T., Jurdic, P., et al. (2001) CD46/CD3 costimulation induces morphological changes of human $\mathrm{T}$ cells and activation of Vav, Rac, and extracellular signal-regulated kinase mitogen-activated protein kinase. J. Immunol. 167, 6780-6785.

Zheng, L. M., Ojcius, D. M., Garaud, F., Roth, C., Maxwell, E., Li, Z., et al. (1996). Interleukin-10 inhibits tumor metastasis through an NK cell-dependent mechanism. J. Exp. Med. 184, 579-584. doi:10.1084/jem.184.2.579

Zielinski, C. E., Mele, F., Aschenbrenner, D., Jarrossay, D., Ronchi, F., Gattorno, M., et al. (2012). Pathogeninduced human TH17 cells produce IFN-gamma or IL-10 and are regulated by IL-1beta. Nature 484 514-518. doi:10.1038/nature10957

Conflict of Interest Statement: The authors declare that the research was conducted in the absence of any commercial or financial relationships that could be construed as a potential conflict of interest.

Received: 01 May 2013; paper pending published: 13 May 2013; accepted: 15 May 2013; published online: 31 May 2013.

Citation: $\mathrm{Ng}$ THS, Britton GJ, Hill EV, Verhagen J, Burton BR and Wraith DC (2013) Regulation of adaptive immunity; the role of interleukin10. Front. Immunol. 4:129. doi: 10.3389/fimmu.2013.00129

This article was submitted to Frontiers in Immunological Tolerance, a specialty of Frontiers in Immunology.

Copyright (C) $2013 \mathrm{Ng}$, Britton, Hill, Verhagen, Burton and Wraith. This is an open-access article distributed under the terms of the Creative Commons Attribution License, which permits use, distribution and reproduction in other forums, provided the original authors and source are credited and subject to any copyright notices concerning any third-party graphics etc. 